\title{
Desventuras da influência política midiática no Brasil pós-1988: uma teoria da demanda por informação política
}

\author{
Fernando Lattman-Weltman ${ }^{1}$
}

\begin{abstract}
O artigo apresenta uma teoria da demanda por informação política e seu modelo é aplicado à análise das sete eleições presidenciais brasileiras após o regime militar. O objetivo inicial da teoria é situar o potencial de influência política e eleitoral dos meios de comunicação sobre as escolhas dos chamados cidadãos comuns e dos militantes, conforme variáveis do contexto político e institucional. Ou seja: por que em determinadas circunstâncias a intervenção midiática parece influir decisivamente sobre as escolhas dos indivíduos e em outras não? Como é possível discernir tais variações sem os limites conhecidos das análises da oferta da informação política, que ou não dão conta da polissemia da recepção ou, quando o fazem, em escala mais reduzida e profunda, não podem ser generalizadas. De acordo com a teoria, a influência midiática é função da utilidade atribuída à informação política, a qual depende da fixação e da intensidade das preferências do eleitor e da margem de risco com que toma suas decisões, as quais, por sua vez, dependem da estabilidade e do grau de polarização política do sistema. São também brevemente indicados alguns dos outros potenciais da teoria.

Palavras-chave: teoria política; influência midiática; Brasil; eleições; militância
\end{abstract}

\section{Introdução}

O campo dos estudos sobre a influência midiática nos processos políticos democráticos, particularmente no contexto brasileiro, vem se aprimorando de modo acentuado há cerca de um quarto de século, com considerável desenvolvimento tanto em termos empíricos quanto naqueles mais propriamente teóricos e metodológicos ${ }^{2}$.

Depois de um período inicial de grande efervescência, em paralelo à retomada das disputas políticas pelo Poder Central, com as primeiras eleições para a presidência da República após o Regime Militar, em 1989, os principais, mas sempre polêmicos, quadros interpretativos dessa jovem tradição de estudos midiáticos voltaram a ser desafiados, a partir de 2006, pela conjunção deveras contraditória de um comportamento políticopartidário cada vez mais sistematicamente parcial da parte dos nossos principais veículos de opinião, com uma eficácia política e eleitoral cada vez mais questionável da interferência

\footnotetext{
1 Universidade do Estado do Rio de Janeiro, Instituto de Ciências Sociais, Rio de Janeiro (RJ), Brasil.

E-mail: <flwnyc@me.com>. Orcid: <http://orcid.org/0000-0002-6021-9798>.

2 Entre as resenhas dessa literatura, ver, por exemplo, Azevedo (2006) e Colling (2006).
} 
narrativa desses mesmos órgãos de comunicação (Lattman-Weltman e Chagas, 2017). Ou seja: se antes de 2006, nas primeiras eleições presidenciais diretas, o campo parecia ser estimulado e beneficiado em suas conclusões - mesmo quando questionado em suas ferramentas (Mundim, 2007) - pela congruência entre as linhas principais de enquadramento narrativo midiático das grandes disputas pelo poder e os resultados principais destas - com as vitórias de Fernando Collor em 1989, Fernando Henrique Cardoso em 1994 e 1998, e até mesmo quando da chegada de Luiz Inácio Lula da Silva ao poder em 2002 -, a partir da reeleição de Lula em 2006 e da vitória de Dilma Rousseff em 2010, isso certamente não ocorreria mais. Ou seja, a partir de 2006 os candidatos petistas teriam sido eleitos contra as intenções visíveis da grande mídia e a despeito de seus esforços sistemáticos (Coimbra, 2007; Azevedo, 2017). Por outro lado, após a acirrada disputa de 2014 e a crise cujo desenlace se deu no impeachment da reeleita presidenta Dilma Rousseff, em 2016, voltou-se, em muitas análises, a tomar como líquida, certa e incontestável, se não exatamente a influência e a interferência dos mais tradicionais veículos de comunicação brasileiros no rumo tomado pelos acontecimentos, ao menos a nova congruência entre estes e o posicionamento da maioria dos veículos mais importantes (consistente, também, com o apoio popular significativo à deposição da então presidenta) ${ }^{3}$.

Por quê? Como explicar tais oscilações?

A princípio, poderíamos naturalmente nos filiar a uma das seguintes alternativas de explicação para tal fenômeno: 1) ou nossas conclusões passadas (de 1989 a 2002) a respeito não somente da congruência, mas da efetiva relação de causalidade - mesmo que não necessariamente exclusiva ou imediata - entre, de um lado, determinada configuração de narrativa midiática do processo de disputa político-eleitoral e, de outro, o seu resultado, já careciam de validade à época - e, portanto, incongruências mais recentes não precisariam ser, a rigor, explicadas (ou podem ser mais bem explicadas por outras hipóteses e teorias); 2) ou nossas análises, teorias e interpretações de outrora não careciam então de fundamento e pertinência, mas alguma mudança significativa no terreno de atuação empírica dos mesmos atores e variáveis principais em ação em tais processos produz agora (ou em certas circunstâncias novas, mais ou menos conjunturais) resultados diferentes. Quer dizer: ou a teoria estava errada, ou mudou a realidade; de tal modo que a primeira não consegue mais dar conta do fenômeno (o que, a rigor, significa que, desde o começo, havia falhas e/ou lacunas importantes nas ferramentas de intelecção utilizadas).

De minha parte, tendo sempre a assumir o princípio de prudência - não tão óbvio ou aceito como se possa imaginar - segundo o qual, na eventualidade de incongruência

\footnotetext{
3 Uma análise sistemática do posicionamento editorial dos chamados principais "jornais de opinião" brasileiros frente ao processo de impeachment de Dilma se encontra, por exemplo, em Guazina, Prior e Araújo (2017). Para relatos jornalísticos, ver, por exemplo, Carta Capital (<https://www.cartacapital.com.br/ blogs/intervozes/a-legitimidade-do-impeachment-tramada-pela-grande-midia>, acesso em 2 set. 2017) e Intercept (<https://theintercept.com/2016/09/01/midia-brasileira-construiu-narrativa-novelizada-doimpeachment/>, acesso em: 4 set. 2017).
} 
entre minha teoria e o real, a falha só pode estar em minha teoria. Necessitando esta, pois, de reforma (e não exatamente o contrário).

Por isso, minha escolha não recai na primeira nem na segunda alternativa acima: nem acho que nossas interpretações passadas sobre o tema careciam totalmente de validade, nem creio que as mudanças empíricas possam ser simplesmente apontadas sem que isso implique a necessidade imperiosa de rever e aperfeiçoar as ferramentas teóricas e conceituais. Ou seja: trata-se de corrigir, completar ou tornar mais sofisticada e eficaz uma mesma teoria que seja, afinal, capaz de dar conta tanto de uma quanto de qualquer outra mudança empírica significativa no fenômeno em questão. Ela tem de ambicionar, pois, ser capaz de dar conta de qualquer realidade (mesmo sabendo que dificilmente irá consegui-lo; ao menos, não individual e efetivamente).

Assim, identifico um mesmo problema essencial quando se trata de inferir determinados efeitos midiáticos de influência política e eleitoral a partir de amostras da oferta de informação política, com base, por exemplo, em análises de conteúdo, enquadramentos, valências etc. Partindo-se da congruência pressuposta - e, de fato, muitas vezes comprovada - entre os sentidos predominantes em tais amostras discursivas e o rumo dos acontecimentos políticos e eleitorais, desprezam-se, contudo, outras variáveis políticas e eleitorais relevantes - que também concorreriam para a explicação dos resultados em questão ${ }^{4}$. Mas, o que pode ser ainda mais comprometedor, faz-se também tábula rasa da polissemia e da diversidade da recepção. Sem desconsiderar a validade, por si só, de tais análises de oferta informacional no que diz respeito à formação das agendas públicas e à compreensão dos modos de intervenção e alinhamentos políticos, ideológicos, ou mesmo partidários, dos meios de comunicação e de sua atuação como atores políticos relevantes (entre outras aplicações) ${ }^{5}$, o problema maior da inadequação metodológica de tais pesquisas para inferir o peso efetivo da variável "influência midiática" em contextos de disputa política democrática se manifesta justamente quando, assim como expus acima, desaparece até mesmo a correlação empírica básica entre as tendências de tal produção discursiva majoritária e os resultados políticos e eleitorais pressupostos e previstos como consequentes. Exatamente o que ocorreu a partir de 2006, nas eleições presidenciais brasileiras (e o que motivou este artigo $)^{6}$.

\footnotetext{
${ }^{4}$ E as variáveis clássicas, digamos, não midiáticas, de interpretação de resultados eleitorais, como o contexto econômico, a oferta de candidatos, as alianças e estratégias de campanha, o poder das máquinas partidárias, a avaliação dos mandatos etc.

5 Com relação aos métodos clássicos de análise da oferta informacional midiática, ver, por exemplo, Porto (2002) e Aldé, Mendes e Figueiredo (2007). Já com relação aos estudos que tentam dar conta da recepção, e certamente o conseguem, para grupos restritos e controlados (ou seja: sendo perfeitamente válidos mas não necessariamente generalizáveis), ver Aldé (2005).

${ }^{6}$ Por isso agradeço à(ao) parecerista anônima(o) que me sugeriu levar em conta, como hipótese alternativa para a possível perda atual de influência dos meios de massa mais tradicionais, a ação de fatores como a fragmentação do campo midiático - provocada pelo advento das redes digitais - e o mais ou menos consequente declínio da capacidade de ampliação dos públicos daqueles mesmos veículos. Sem negar a relevância histórica de tais desenvolvimentos, diria apenas que atribuir peso determinante a fatores
} 
Nesse sentido, proponho-me neste artigo a explicitar o que chamo de uma teoria da demanda por informação política na análise das conjunturas que presidiram essas sete eleições presidenciais pós-redemocratização, no sentido de testar a consistência e o rendimento teórico da seguinte hipótese: a paulatina estabilização do sistema político brasileiro (1), ocorrida ao longo do atual período democrático de disputas diretas pelo Poder Central, de 1989 até 2014, de par com a evolução e as oscilações de polarização/despolarização política (2) do mesmo sistema são as variáveis independentes que, num primeiro momento, ocasionaram uma relativa perda de influência e poder de interferência política (eleitoral) por parte dos nossos mais prestigiosos meios de comunicação. Por isso, mídias que teriam tido peso considerável na definição dos rumos das primeiras eleições presidenciais, após o regime militar - de 1989 a 2002 -, tornaramse em seguida (de 2006 a 2014) elementos secundários, incapazes de se contrapor a fatores típica e tradicionalmente decisivos em contextos históricos de institucionalização democrática - como a conjuntura e as expectativas econômicas, e os índices de popularidade dos governantes (Abramowitz, 1988; Lewis-Beck e Rice, 1984). Tendo como novo marco as eleições de $2014^{7}$, contudo, mudanças no contexto global, mas acima de tudo o acirramento das tensões e da radicalização política no contexto nacional, parecem ter ocasionado uma reversão de tais tendências, com a mídia assumindo nos últimos anos, ao menos à primeira vista, uma nova forma de protagonismo em tal processo de crise. De tal modo que até mesmo a estabilidade do sistema se viu, por fim, abalada com a crise que levou à deposição em 2016, por meio tão excepcional e traumático, da presidenta eleita.

Como procuro explicitar adiante, meu modelo teórico pressupõe, portanto, a ação dessas duas variáveis independentes (estabilização e polarização) sobre duas outras variáveis dependentes (mas também intervenientes) - a) formação e intensidade de preferências políticas dos cidadãos, e b) margem de risco associada a decisões políticas para os mesmos indivíduos. Essas variáveis a) e b) então afetam a utilidade atribuída à informação política por aqueles e, consequentemente, a capacidade de influência dos meios de comunicação sobre eles. Ou seja: a demanda por informação política por parte dos chamados cidadãos comuns seria afetada sobremaneira pelo grau de fixação e intensidade das preferências políticas de tais indivíduos, de par com a margem de risco associada às decisões políticas que estes tenham de tomar, as quais, finalmente, são função da estabilidade e da polarização relativas do sistema político mais amplo.

endógenos ao campo midiático como estes equivaleria a continuar tomando como não problemático o pressuposto geral de influência política da mídia, e a seguir menosprezando importantes variações especificamente políticas e institucionais conjunturais - o que me parece cada vez mais decisivo incorporar, e exatamente um dos aspectos mais fecundos de minha teoria, aqui apresentada. Com efeito, as variáveis endógenas sugeridas (e outras similares) me parecem totalmente incapazes de explicar, por exemplo, a possível recuperação de poder de influência das mídias no contexto do impeachment de 2016, depois de "perderem" as últimas três eleições presidenciais (coisa que, como podemos observar adiante, minha teoria talvez seja capaz de fazer).

7 Mas certamente tendo origem quase uma década antes com a crise do chamado Mensalão. 
Como entender então a ocorrência efetiva de maior radicalização política (ou mesmo protopartidária) dos principais veículos formadores de opinião, pelo menos desde 2005, com a eclosão da crise do Mensalão, ao mesmo tempo em que, como propus, acontece - ao menos até 2014 - uma crescente ineficácia eleitoral desses meios nos pleitos de 2006, 2010 e, até certo ponto, ainda em 2014? Por que justamente no momento em que possivelmente se observa o mais alto grau de engajamento (proto)partidário de tais mídias contra um determinado grupo político - e em que, supõe-se, elas teriam atingido elevado nível de interferência no jogo -, isso não se traduz em resultados eleitorais congruentes (tal como pode ter acontecido no passado recente anterior, e talvez até com menor intensidade e facciosismo $)^{8}$ ?

Um dos fatores que explicam este e outros aparentes paradoxos é a distinção entre os modos de operação das variáveis dessa economia, quando, em vez de observarmos o comportamento informacional do chamado cidadão comum, nos atemos àquele dos chamados "militantes": definidos aqui como sendo os indivíduos que, por qualquer razão, ultrapassam determinado limiar de interesse e de envolvimento na vida política - e também, portanto, no desenvolvimento de hábitos e demandas específicas por informação relativa -, o que os leva a se tornar muito mais sujeitos à influência dos meios (mesmo que por oposição ou negatividade) ${ }^{9}$. Ou seja: observada e experimentada a realidade política conjuntural com as lentes "bem informadas" e próprias ao "militante", se apresentariam para ele como muito mais relevantes e decisivos os issues e rationales eleitorais específicos - sejam estes mais propriamente ideológicos e/ou partidários -, privilegiados pela cobertura política midiática, ao passo que, para as escolhas do cidadão comum típico-ideal, muito menos "informado", outras percepções e atalhos cognitivos poderiam pesar mais na decisão do voto ${ }^{10}$.

$\mathrm{E}$, desse modo, um dos resultados possivelmente contraintuitivos da aplicação dessa teoria é a constatação de que militantes - entendidos aqui em sentido amplo (o que inclui, portanto, quaisquer indivíduos engajados e geralmente tidos como "bem informados"; jornalistas e cientistas sociais típicos, inclusive) - estão sempre mais

\footnotetext{
${ }^{8}$ Assim como podem ter voltado a fazê-lo, como suponho, desde 2013, ou 2014.

${ }^{9}$ A definição de militante utilizada aqui se enquadra, portanto, em linhas gerais, nos marcos definidos pela teoria econômica da democracia de Downs (1957). Esse autor elabora uma tipologia de diferentes tipos de atitudes para com a política e, assim, chama a atenção para as consequências desse fato sobre nossa compreensão da racionalidade política. Um dos personagens descritos por Downs é o que chama de "agitador" (e que prefiro chamar de "militante"): "... tendo se informado o suficiente para estar certo de suas próprias decisões, agitadores são praticamente imunes à persuasão de seus adversários (...). Mas, seja o motivo o simples retorno de um favor político, ou o altruísmo mais idealista, o importante é que os agitadores estão dispostos a investir recursos escassos - pelo menos tempo, e talvez mais - para mobilizar" (Downs, 1957 , p. 84. Tradução minha). Prefiro utilizar o termo militante, em vez de agitador, porque (ao menos) no Brasil a palavra "agitador" possui, na maior parte das vezes, um tom pejorativo. Há outras diferenças entre o modo como caracterizo o militante e a forma com que Downs trabalha com seu "agitador" (e que não cabe explorar aqui). Mas é clara a minha dívida para com seu trabalho.

10 Sobre a noção de "atalhos cognitivos" aplicada ao comportamento eleitoral típico-ideal, ver Downs (1957) e Popkin (1994).
} 
expostos ao fluxo informacional midiático e assim se tornam potencialmente muito mais mobilizáveis, e, portanto, manipuláveis, pela mídia (mesmo que contraditoriamente). E também muito mais, digamos, "alienáveis" em relação aos efetivos graus gerais de estabilização e despolarização política de uma democracia, se comparados aos chamados cidadãos comuns (a quem muitas vezes se menospreza, e/ou se acusa de inconsistência, de irracionalidade política) ${ }^{11}$.

\section{Uma teoria da demanda por informação política}

Pressuponho então que: 1 ) duas principais variáveis independentes: a estabilidade e inteligibilidade do sistema político (partidário) (EP) e a polarização do sistema político (PP) afetam duas outras, dependentes (mas também intervenientes): a margem de risco contingentemente associada a opções políticas (MR) e a fixação/intensidade das preferências ( $\mathrm{Pr}$ ) dos indivíduos; 2) por sua vez, $\operatorname{Pr}$ e MR afetam a variável mais dependente (mas focal) que é a utilidade atribuída à informação (UI); 3) finalmente, UI define os graus de influência midiática (IM) a que estaria sujeito o demandante por informações políticas.

Assim, quando falo sobre EP quero me referir à estabilidade e à inteligibilidade de um sistema político: essa estabilidade, num sentido muito pragmático, se desenvolve a partir da simples manutenção e iteração das principais regras do jogo político, e significa que, mesmo se eventualmente insatisfeitos ou decepcionados com os resultados concretos, mais ou menos contingentes desse sistema, esses cidadãos aprendem com a prática não só o que esperar, mas também como lidar habitualmente com tal sistema, a fim de tentar realizar as suas preferências ou minimizar suas perdas ${ }^{12}$. O contexto típico-ideal contrário seria justamente aquele em que alterações formais e/ou práticas no funcionamento do mesmo sistema introduziriam considerável incerteza e insegurança sobre meios e fins, de modo que os atores não possuíssem mais referências habituais e previsíveis sobre o que e como fazer para defender seus interesses.

Quanto a PP, trata-se de uma variável contextual, relacionada com as muitas maneiras pelas quais um sistema político torna-se mais ou menos polarizado politicamente. Essa polarização pode se dar em torno de issues e programas políticos, em torno de ideologias (mais ou menos sistemáticas) e em torno de grupos, líderes, séquitos e facções.

\footnotetext{
${ }^{11}$ Entre as possíveis consequências inusitadas de tais processos, pode estar justamente o aumento da polarização política e de seus efeitos em contexto de relativo aumento dos patamares de engajamento e do número de novos militantes e/ou simpatizantes - ocasionado, talvez, por exemplo, pela massificação do acesso às redes digitais (Martuccelli, 2015).

12 Desde que, é claro, o sistema político em questão se mostre minimamente permeável e acessível aos "cálculos", expectativas de algum sucesso e projetos futuros de tais atores. Ou seja: desde que haja um mínimo de equilíbrio de poder e perspectiva de alternância de grupos ou agendas conjunturalmente hegemônicas. Ou, enfim, no sentido preciso do famoso cálculo poliárquico dahlsiano de custos de tolerância comparativamente inferiores aos custos de supressão de adversários políticos (Dahl, 1997).
} 
Também pode evoluir num continuum de maior ou menor tolerância mútua entre adversários ou inimigos políticos, movendo-se eventualmente no sentido de um contexto mais radicalizado, ou mesmo protoinsurrecional, até, afinal, a própria guerra civil ${ }^{13}$.

Por sua vez, preferência ( $\mathrm{Pr}$ ) tem aqui o mesmo sentido comum que a palavra carrega geralmente em qualquer descrição do comportamento político ou econômico de um indivíduo: atitudes contingentes dos indivíduos frente a qualquer objeto, material ou ideal, que podem levar a uma escolha, decisão ou manifestação de modo perfeitamente autorreconhecido por essa pessoa. Isto é: qualquer atitude, positiva, negativa ou neutra, em relação a qualquer sujeito, objeto ou ideia definidos - e em comparação com alternativas disponíveis -, e que, mesmo se relativamente contingente e instável, não deixa de ser claramente autoconsciente para o indivíduo e facilmente atribuível a ele ${ }^{14}$.

Já a margem de risco contingentemente associada a opções políticas (MR) referese à importância atribuída pelo indivíduo a qualquer decisão que ele precise fazer em termos dos riscos que atribui à possibilidade de fazer a escolha errada nesse caso. A margem de risco varia de acordo com a situação específica de contexto de tomada de decisões. Na medida em que essa situação apresenta-se como grave - e, é claro, razoavelmente dependente para a sua resolução ou agravamento das escolhas feitas pelos nossos indivíduos ${ }^{15}$-, maior o risco atribuído contingentemente a uma decisão possivelmente errada. Mas se a situação parece ser comum, ou não ter consequências relevantes quaisquer que sejam as escolhas a serem feitas pelo indivíduo, a MR será menor.

\footnotetext{
13 Em suma: polarização política é entendida aqui como sendo todo aquele processo pelo qual atores políticos (indivíduos, grupos, facções e partidos) se alinham em torno a posições opostas com relação a qualquer tema ou controvérsia, e em que, no entanto, alguma escolha ou decisão coletiva terá de ser tomada, com algum custo material ou moral para ao menos a parte perdedora. Os graus de intensidade, exclusivismo e animosidade da polarização podem variar em escalas passíveis de tipologização, mas seu traço característico é o fato de que: 1) a partir de certo ponto o processo pode se alimentar de si mesmo, gerando um círculo vicioso de radicalização; 2) à medida que se torna mais intenso e/ou abrangente, tal processo de polarização tende a reduzir qualquer margem ou possibilidade de neutralidade ou indiferença para os demais participantes do ambiente polarizado (Fiorina, Abrams e Pope, 2011; Abramovitz e Saunders, 2008).

14 "Para descrever preferências, nós temos de nos dar conta, primeiro, de que elas são distintas das escolhas. Preferências descrevem o quanto valorizamos ou desejamos coisas. Escolhas são aquilo que selecionamos. Nossas preferências guiam nossas escolhas, e nossas escolhas revelam (parcialmente) nossas preferências" (Page, 2007, p. 241. Tradução minha). Assim, minha preferência por uma noção como a de "preferências", em vez de outras similares, ou por conceitos próximos, como, por exemplo, "posições", se deve à intenção de enfatizar o caráter genérico do processo básico de escolher e de decidir, e, portanto, de intencionalmente aproximar o fenômeno das opções políticas de quaisquer outras instâncias de escolha. É claro que eu poderia ter me utilizado da noção de "posições" em vez de "preferências" (tal como Fiorina, Abrams e Pope (2011) a utilizam para enfatizar a diferença entre "posições" e "escolhas"). Não o fiz porque compreendo que "posição" tende a significar uma postura mais definida frente a qualquer assunto - tal como às vezes se espera de manifestações de entrevistados de pesquisas de opinião sobre temas polêmicos (e cuja diferença frente ao conceito de "escolha" é central para o convincente argumento de Fiorina e seu parceiros contra a suposta efetividade da existência de uma autêntica "guerra cultural" na América há cerca de cinco anos). Enquanto "preferências" pode se referir muito mais a inclinações e a predisposições não necessária e consistentemente definidas - embora possivelmente fortes - dos indivíduos, as quais usualmente os conduzem a escolher esta ou aquela alternativa (seja na política ou em qualquer outra circunstância).

$15 \mathrm{O}$ que inclui como uma importante variável o sabidamente problemático valor instrumental que se atribui ao voto individual em democracias contemporâneas e de grandes contingentes eleitorais (Grofman, 1993).
} 
A variável mais dependente, porém mais importante aqui, é, naturalmente, UI, a saber, a utilidade contingentemente atribuída à informação. Em contextos rotineiros, não dramáticos e bastante previsíveis, não há grandes incentivos para fazer a aquisição de (nova) informação valer os custos da sua obtenção - custos monetários, mas principalmente em termos de tempo gasto em procura, verificação e absorção. Ao contrário, quando a incerteza e os riscos aumentam, a utilidade da informação deve também aumentar e os custos para obtê-la devem recuar, relativamente. Conforme aumenta ou diminui a UI para um dado indivíduo, aumenta ou diminui proporcionalmente também a influência midiática (IM) a que ele se encontra tipicamente sujeito, uma vez que os meios de comunicação são os principais fornecedores de informação política subsidiada para esse indivíduo.

Como cada variável opera e se relaciona com as demais?

EP significa que existe uma relação importante entre a forma como um sistema político democrático se estabiliza e se torna mais inteligível para os seus cidadãos e como se dá, principalmente, a fixação relativa das identidades políticas e preferências (PrFx) destes. À medida que um sistema e suas regras básicas e rotinas são reiterados, com alterações insignificantes, e suas forças políticas são cada vez mais conhecidas do público, principalmente através de seu sistema de partidos, de seus líderes e de plataformas e compromissos assumidos em cada eleição ou luta para votar políticas e legislação - mas também, possivelmente, na interação cotidiana entre esses atores políticos e as forças principais, movimentos e instituições da sociedade - torna-se mais fácil para o cidadão médio que experimentou essa trajetória desenvolver e ajustar seus "atalhos", suas identificações e sua própria identidade, seu lugar próprio no espectro ideológico, seus compromissos com determinados programas e com a história de determinados partidos e/ou líderes e, por último, mas não menos importante, estabilizar certa hierarquia de preferências que costumam guiá-lo nas escolhas políticas que se colocam a cada oportunidade. Sendo assim, acredito que não só o aumento de EP tenderia a aumentar PrFx, mas também que a estabilidade e a inteligibilidade do sistema político fomentado dessa forma são os fatores mais importantes e independentes para influenciar a fixação relativa das preferências individuais. Para enfatizar a importância global da relação, eu diria então que, se EP $=x$, então $(\rightarrow) \operatorname{PrFx}=2 x$. Se, entretanto, o sistema sofre fortes abalos em suas regras principais, ou em sua oferta de alternativas políticas - seja em termos de siglas ou lideranças -, a fixação de preferências pode ser posta em xeque, pois a adequação entre meios e fins torna-se mais obscura e incerta (ou, na linguagem downsiana, os atalhos não funcionam mais). De qualquer modo, negativa ou positiva, a dependência de PrFx com relação a EP é a mesma.

Do mesmo modo, podemos dizer que a relação entre a polarização política (PP) e as intensidades das preferências (PrIn) segue, genericamente, a mesma direção: se PP = y $\rightarrow \operatorname{PrIn}=\mathrm{y}$. Ou seja: em um contexto despolarizado, indivíduos podem, naturalmente, desenvolver suas próprias preferências ou hierarquias de preferência fixas e/ou 
relativamente intensas, mas isso dificilmente terá algum significado político real se não houver real interesse por parte de empreendedores políticos em explorar tal fato. Desse modo, tomo como uma premissa do modelo que a forma com que a polarização política afeta as preferências da grande maioria dos cidadãos é fortemente dependente de iniciativas de empreendedorismo político; quer dizer: quase nunca é automática ou espontânea para o eleitor médio, mas sim dependente de alguma mediação, da interpelação de algum ator partidário (em sentido amplo) ${ }^{16}$. Não só, pois, os candidatos, partidos, agentes públicos, grupos de interesse, ideólogos e líderes sociais, mas também, é claro, os meios de comunicação (mais ou menos parciais). Assim, presumo que especialmente a intensidade das preferências de um indivíduo irá evoluir no mesmo sentido de PP e vice-versa: uma vez que aumente a polarização, as preferências dadas, mas agora politicamente mobilizadas, tenderão a ser sentidas de uma forma mais intensa. Porém se a polarização recua, as preferências políticas dos indivíduos não serão normalmente mais estimuladas e intensificadas.

A outra variável dependente importante do modelo que evoluirá como uma resposta às mudanças de EP e de PP é a margem de risco contingentemente associada a opções políticas (MR). Se a relação entre estabilidade e preferências é de tal modo positiva, não podemos dizer o mesmo da forma como EP afeta MR. Na verdade, cada aumento em EP tenderia a levar a uma diminuição da MR. Se, numa situação diferente, EP permanece positiva, mas PP aumenta - ou seja: maior polarização -, então MR pode tornar-se mais evidente e preocupante, dependendo das características específicas do processo de polarização. Quaisquer que sejam as especificidades de cada processo contingente de polarização, o fator importante a contribuir para o aumento das margens de risco associadas às decisões dos indivíduos é sempre, primeiro, o aumento genérico da incerteza e, segundo, alguma espécie de certeza muito específica - provocada por um processo de polarização - de que os custos de uma eventual derrota política conjuntural tornam-se mais difíceis de suportar. Assim, por exemplo, a MR sempre deverá reagir mais sensivelmente diante de fatores conjunturais como, por exemplo, crises econômicas, reformas profundas ou alterações institucionais que afetem ou ameacem afetar interesses autoconscientes e/ou direitos já adquiridos.

Temos aqui, portanto, um esboço de como a estabilidade e a polarização políticas impactam a fixação e a intensidade das preferências dos cidadãos típicos, bem como as margens de risco associadas a suas escolhas políticas. Podemos ver agora como as variáveis dependentes afetam a utilidade que atribuímos à informação.

Assumo então que Pr, por si só, tende a manter uma relação de proporcionalidade negativa com a utilidade da informação (UI): se as preferências são fixas e intensamente

\footnotetext{
${ }^{16}$ Cabe a Schumpeter (1961) a formulação aqui utilizada da noção de empreendedorismo político e de seu papel fundamental na formação das agendas políticas e eleitorais, em contraste com as concepções espontaneístas ou sociologicamente substantivistas da representação. Para uma crítica dessas concepções, ver Lattman-Weltman (2014).
} 
sentidas, menos valiosa tenderá a ser considerada a informação nova. Isso se dá por causa de certa inércia, segundo a qual, na ausência de grandes razões contextuais para que o indivíduo em questão se sinta inseguro e reveja suas preferências, ou hierarquias de preferências, toda nova informação tenderá a ser descartada ou absorvida de acordo, por assim dizer, com coordenadas-padrão, previamente estabelecidas para cada indivíduo ${ }^{17}$. Se isso acontece com novas informações gratuitas, será ainda menos provável que em tais circunstâncias um típico cidadão comum e racional gaste qualquer recurso relativamente escasso para adquirir qualquer informação cujo custo seja intransferível (Downs, 1957). Se as preferências são fixas, mas menos intensas, pode ser mais fácil encontrar indivíduos mais propensos a se abrir aos fluxos de informação novos e gratuitos. Mas, ainda assim, não haveria grandes incentivos para rever preferências. Desse modo, podemos tomar como regra genérica a ideia de que sempre que um sistema político é rotinizado, a informação política nova torna-se praticamente irrelevante para o cidadão médio. Pode-se dizer que quando $\mathrm{Pr}=\mathrm{z} \rightarrow \mathrm{UI}=-\mathrm{z}$.

Mas a variável mais premente em matéria de interferência na utilidade atribuída à informação é, de longe, o que chamei de margem de risco associada a escolhas e decisões políticas (MR). Isso é tão importante que pressuponho sempre que se $M R=w \rightarrow U I=2 w$. Assim, se a margem de risco tende a crescer cada vez que rotinas são quebradas, ou a cada aumento de polarização, ou ainda mais dramaticamente quando ambos os processos ocorrem simultaneamente, então haverá um aumento acentuado na procura de informação, e um aumento dramático do valor atribuído à informação.

o importante a se ter em mente é o fato de que a informação política não terá intrinsecamente nenhum valor ou utilidade imutáveis ou universais, independentemente da demanda, ou dito de outro modo, da utilidade geral atribuída contextualmente à informação pelos indivíduos (UI). Isto é, no registro metodológico que proponho, não importa tanto o conteúdo narrativo em si da informação, mas sim o contexto de sua recepção e a economia crítica que o caracteriza: ou seja, quão premente é, em tais circunstâncias, a necessidade e a urgência por se informar e, consequentemente, qual o valor atribuído a tal insumo, seja qual for ou venha a ser o seu conteúdo informativo, supostamente intrínseco. Dito ainda de outro modo: uma mesmíssima informação ou conteúdo narrativo - um escândalo, por exemplo - pode causar impactos terríveis ou simplesmente nenhum, conforme a utilidade relativa atribuída conjunturalmente, contextualmente, à aquisição de informação política pelo "consumidor".

\footnotetext{
17 De um modo similar à descrição que Popkin faz do processo informacional básico do ato de votar: "Estudar as pistas (cues), ou atalhos informativos, que as pessoas usam ao votar é estudar como as pessoas se valem de informações com as quais compõem suas imagens de candidatos e governos. Tais pistas permitem que os eleitores recuperem crenças sobre pessoas e governos a partir dos quais podem gerar ou recordar cenários ou roteiros (scripts), como se diz em psicologia. Um pouco de informação pode percorrer um longo caminho porque as pessoas podem gerar muitos cenários e ideias a partir de diferentes pistas ou dicas. Elas podem absorver algumas dicas e, em seguida, completar suas imagens com a ajuda de seus 'valores padrão'" (Popkin, 1994, p. 16. Tradução minha).
} 
A UI dependerá essencialmente, portanto, e em última instância, de amplos ambientes institucionais e do contexto político específico. Como veremos abaixo, isso tem consequências específicas para a questão controversa da influência dos meios de comunicação de massa na política.

Mas as circunstâncias e relações entre as variáveis podem ser muito diferentes a depender de que público específico demanda as informações. Em especial se, em vez de cidadãos comuns, estivermos diante de militantes.

\section{Cidadãos comuns, militantes, utilidade da informação e influência midiática}

Para os propósitos dessa teoria, e conforme explicitei acima ${ }^{18}$, um militante pode ser definido basicamente como alguém que, seja por que razões, cruzou um limite que o diferencia do cidadão comum, e a partir de agora tem um bom motivo para investir mais recursos na vida política. Essa diferença que a princípio se apresenta como de grau - ao qual poderíamos atribuir um limiar ou patamar - pode, no entanto, se mostrar como sendo, na verdade, de natureza: já que, enquanto o cidadão comum tende a desvalorizar, se não a simplesmente julgar irrelevante, o seu poder individual de interferência política exercido basicamente através do voto -, o militante tende a julgar indispensável a sua interferência política, no sentido de, através dela, ajudar a definir os rumos dos acontecimentos.

Assim, se a estabilidade (e a inteligibilidade) de um sistema político (EP) é uma variável muito importante para influenciar as preferências ( $\mathrm{Pr}$ ) do cidadão comum, quando se trata de um militante típico o seu efeito direto é bem menos significativo. Isso ocorre porque, para este, a estabilidade do sistema político em que atua é lida e se torna inteligível através de lentes mais tendenciosas e especificadas (e que não funcionam para os cidadãos comuns): aquelas lentes que se formam através de uma experiência "partidária" muito mais intensa. Seja qual for a sua identidade política, para um militante o desempenho geral do sistema político será sempre mediado pelas especificidades institucionais e conjunturais de seu ambiente político mais imediato, com suas pautas e questões específicas, seja qual for a natureza ou o objeto central de sua militância: partidária, corporativa, ideológica, confessional, comunitarista etc. Posso, pois, grosso modo, sugerir que, a princípio, para o militante típico, se EP $=x \rightarrow \operatorname{Pr}<x$.

Por isso mesmo, a variável realmente importante, nesse caso, para influenciar a Pr de um militante é a polarização política (PP). No entanto, para o verdadeiro militante, PP na verdade é quase uma constante. O que significa que, para ele, o cenário político é sempre polarizado. Podem variar os graus de polarização, mas estes serão aqui sempre mais elevados se comparados com o modo como o mesmo fenômeno é percebido e atua sobre cidadãos comuns.

\footnotetext{
18 Ver a nota 9.
} 
Desse modo, a margem de risco (MR) associada às escolhas de um militante pode e provavelmente sempre assumirá para ele um tom mais dramático, especialmente se comparado ao papel usual que tal variável desempenha no ambiente político típico do cidadão médio comum. E por isso a utilidade da informação (UI) será sempre maior ou bem mais elevada para o militante típico. Nas situações políticas mais rotinizadas, as informações já serão comparativamente mais relevantes para ele por conta de seus compromissos específicos com a ideologia ou o programa do "partido"19. Mas em qualquer cenário político excepcional será ainda mais decisivo para ele ter acesso a informações confiáveis e abundantes. Nos piores cenários políticos, pode se tornar não apenas uma questão de chances de vitória, mas também de sobrevivência.

De acordo com o modelo, como vimos, o valor e a utilidade da informação nunca são absolutos, ou imutáveis, muito menos redutíveis a seu conteúdo narrativo, mas sim dependentes, no que concerne especificamente ao seu valor de uso, do contexto político e das instituições, e também da natureza do envolvimento dos seus consumidores e reprodutores com o sistema político. Ou melhor: com o sistema geral e seus muitos subsistemas internos. O que também significa que as instituições com poder global ou maior capacidade de controlar os fluxos de informação mais importantes da sociedade como veículos de comunicação de massa - certamente serão, provavelmente, por si sós, bastante poderosas e influentes, mas não necessariamente tão influentes e decisivas como por vezes se supõe.

A sua capacidade de influenciar e orientar de forma mais independente resultados políticos contextuais irá variar de acordo com a utilidade atribuída à informação por parte dos cidadãos comuns, o que aqui depende de (1) se as preferências entre esses cidadãos são menos fixas, porém mais intensas; (2) se as margens de risco são consideradas relativamente elevadas; (3) o que, naturalmente, depende do quanto a configuração global política é mais ou menos contextualmente estabilizada; (4) e polarizada.

Se tivesse que abreviar essa capacidade de influência dos meios de comunicação como IM, então poderia dizer que, quando UI varia, IM tende a variar na mesma direção. No entanto, essa relação entre UI e IM não será, naturalmente, exatamente proporcional, por uma série de razões: 1) os chamados veículos de comunicação de massa não são os únicos, nem necessariamente os mais confiáveis, provedores de informação política, embora, por vezes, pareçam quase onipresentes e incontornáveis, em especial quando o seu consumo se torna um hábito (ou vício). As pessoas adquirem informações de muitas outras fontes que podem não ser tão poderosas e/ou abrangentes como tais meios hoje mais tradicionais, mas que podem ser consideradas muito mais confiáveis, tal como a informação trazida por outras pessoas cuja opinião importa para as primeiras, seja por razões de prestígio social, conhecimento (presumido), integridade etc. ${ }^{20} ; 2$ ) o uso comum

\footnotetext{
$19 \mathrm{Ou}$, no caso de militantes "profissionais", ou "corporativos", por força das urgências políticas particulares de seus métiers e bases.

${ }^{20}$ Como advoga a clássica teoria da "influência pessoal" de Lazarsfeld e Katz (2006).
} 
do rótulo genérico "mídia" tende a amalgamar ou homogeneizar o que muitas vezes é especialmente em ambientes politicamente mais pluralistas - uma realidade composta, fragmentada, polissêmica e contraditória, envolvendo muitas mídias e veículos diferentes: jornais, revistas, estações de rádio, múltiplos canais de televisão, abertos ou pagos, sites inumeráveis, redes sociais ${ }^{21}$; 3 ) mesmo o mais profissional veículo de massas não pode controlar completamente suas próprias emissões e menos ainda a recepção delas. 0 problema do controle da recepção ocorre devido à natureza polissêmica da realidade sociocultural e à irredutibilidade do indivíduo, mas o relativo ao controle das emissões também é considerável porque os veículos de comunicação de massa mais clássicos - e ainda influentes -, como jornais diários e redes de televisão, costumam lidar todos os dias com muita matéria-prima de informação e muito pouco tempo para processá-la em escala industrial. Assim, mesmo que em função de configurações políticas mais dramáticas, trazidas pelas principais variáveis do modelo, a utilidade das informações cresça a ponto de tornar-se crucial para o típico cidadão comum, isso não implica necessariamente que a capacidade de influência da mídia possa ser considerada tão eficiente quanto os emissores poderiam desejar (ou seus críticos os acusam de ser) ${ }^{22}$.

O relacionamento habitual entre utilidade da informação e influência da mídia pode, pois, ser aproximadamente escrito da seguinte (e precária) forma: se UI $=\mathrm{v} \rightarrow \mathrm{IM}<\mathrm{v}$.

Apliquemos então esse modelo a contextos históricos concretos, no sentido de construir hipóteses capazes de auxiliar em uma compreensão mais sofisticada dos modos como a mídia pode ganhar ou perder poder de influência sobre diferentes grupos de consumidores da informação.

\footnotetext{
21 Mais uma vez agradeço à(ao) parecerista anônima(o) que me sugeriu incorporar outras variáveis midiáticas endógenas - diversidade de consumo, credibilidade das fontes etc. - como fatores também intervenientes sobre a demanda, pela oportunidade de reiterar que minha teoria se enquadra justamente num esforço "econômico" de interpretação do fenômeno da influência política midiática, com foco apenas na demanda - daí a simplicidade reducionista da fórmula "IM=UI/2" -, e sem a necessidade de introdução, no modelo, de variáveis midiáticas endógenas, que são mais relacionadas à oferta informacional (variáveis que de modo algum desprezo nos meus pressupostos - como o demonstra o trecho a que esta nota se refere mas que não creio ser necessário incorporar operacionalmente ao modelo).

22 É claro que não se podem descartar as possibilidades, frequentemente denunciadas, não somente da redução do noticiário a verdadeiros "sambas de uma nota só", nem, em escala ainda mais concentrada, de convergência de diferentes mídias em torno do agendamento e do enquadramento similar de um mesmo e reduzido leque de assuntos. Mas, de novo, isso não elimina a irredutibilidade e, por assim dizer, a relativa autonomia dos diferentes modos de recepção de um mesmíssimo conteúdo narrativo. Enquanto alguns receptores podem se convencer cada vez mais da verdade de um determinado enunciado a cada reiteração deste, outros podem se opor cada vez mais não só a admitir a sua simples veracidade como também podem passar a desacreditar cada vez mais, ou mais irremediavelmente, de tal fonte, ou fontes reiterativas. São essas velhas e insuperáveis indeterminações que afligem qualquer tentativa de generalização mais ambiciosa de possíveis efeitos presumíveis e atribuíveis ao conteúdo de ofertas informacionais e discursivas. E que em geral restringem as análises de discurso, enquadramentos e valências a diagnósticos - sem dúvida, muitas vezes válidos e importantes - acerca dos emissores, de suas "intenções" e "estratégias". Mas não respondem, como aqui argumento, às principais perguntas sobre as oscilações do "poder midiático".
} 


\section{Influência midiática no período 1989-2014}

Antes de prosseguir, é preciso lembrar o leitor de que, se, por um lado, considero razoavelmente acurada (mesmo que sintética) a seguinte análise histórica do período em questão - em função da operacionalização das variáveis do modelo - por outro lado, a formalização matemática deste (e obviamente os resultados consequentes) tem pretensão meramente ilustrativa e, por assim dizer, demonstrativa apenas da consistência lógica do exercício ${ }^{23}$.

Para aplicar esse modelo ao período das eleições presidenciais brasileiras pósRegime Militar, seria necessário então, em primeiro lugar, estabelecer o desempenho, a cada contexto eleitoral, das variáveis independentes: estabilidade política (EP) e polarização política (PP).

Conforme explicitei acima, a noção de estabilidade política que utilizo se refere somente à manutenção das regras do jogo político e eleitoral em suas linhas gerais. À medida que essas regras são reiteradas e novas eleições se realizam, sem grandes alterações - inclusive no que diz respeito ao sistema de partidos -, pressuponho, portanto, que se amplia entre os participantes do jogo o conhecimento prático e estratégico referente a ele. Ou seja: não somente os atores tendem a aprender mais facilmente como se joga, o que se pode e não se pode fazer, mas também quais são as principais opções - individuais e coletivas - e quais estratégias seguir no sentido de maximizar a utilidade de seu voto (seja qual for o conteúdo específico de tal utilidade); quer dizer, quais as melhores formas de "ganhar" ou, pelo menos, de não perder muito (dadas as alternativas específicas a cada eleição). Assim, suponho um índice linear de evolução de EP a cada reiteração do mesmo jogo, com as mesmas regras e participantes estratégicos: 0 no primeiro jogo, 0,25 no segundo, e assim por diante. A partir de um determinado ponto (que mais ou menos arbitrariamente defino como ocorrendo na quinta reiteração consecutiva do jogo), a probabilidade de apreender algo de novo, em termos estratégicos, torna-se praticamente irrelevante e o índice se estabiliza em seu ponto positivo máximo (1), desde que, é claro, as regras sigam basicamente inalteradas. Se, ao contrário, há uma nova mudança significativa de regras, ou na estrutura da oferta de candidaturas e opções de policies, a contagem volta à estaca zero ${ }^{24}$. Ou seja: o que se mensura aqui é simplesmente o grau

\footnotetext{
23 Não obstante, por força justamente de minha aposta nessa consistência lógica, embora não possa no momento comprovar empiricamente - nem muito menos tenho a pretensão de prová-lo matematicamente com o modelo -, aposto na pertinência empírica do diagnóstico a seguir e, mais ainda: acredito no potencial do modelo (e sua teoria) para explicar e até mesmo prever outros processos históricos semelhantes.

${ }^{24} \mathrm{Na}$ verdade, seria possível teorizar acerca de retrocessos menos radicais se, mantidas as regras principais, houvesse alguma alteração muito importante na estrutura de oferta de candidaturas. Pensemos, por exemplo, nos efeitos sobre o sistema partidário de alterações como a proscrição, ou, ao contrário, a permissão de participação legal de certas legendas, antes proscritas: como as que ocorreram com o(s) Partido(s) Comunista(s) no Brasil em 1947 e em 1985; de um dia para outro eleitores podem ser privados de exercer suas "estratégias" e dar consequência a suas preferências (ou de alterá-las em função de novas alternativas oferecidas), sem que as regras gerais do sistema eleitoral sejam propriamente modificadas. De
} 
relativo de incerteza com relação ao jogo político (eleitoral), devido única e exclusivamente à manutenção ou não das regras institucionais e de seus principais atores. Porém, quando as regras são formalmente mantidas, mas seus resultados afetados de modo brusco ou carente de legitimidade - como se poderia argumentar no polêmico caso do impeachment de Dilma Rousseff -, o efeito de desestabilização com base na (im)previsibilidade das regras do jogo poderia ser o mesmo de uma brusca mudança formal de regras (se não pior; pois aqui se arrisca a própria validez das regras formais e suas garantias para todos os jogadores, vencedores ou perdedores).

A outra variável independente, como visto, é a polarização política (PP). Ao contrário da anterior, essa é uma variável eminentemente conjuntural, podendo haver evoluções até certo ponto dramáticas de um momento para o outro (no caso aqui tratado, de uma eleição para outra). Nesse sentido, elaborei uma tipologia de formas de polarização política que obviamente se refere a processos que, além de típico-ideais, podem apresentar uma evolução linear - da menor para a maior intensidade, e vice-versa - e que, inclusive, podem mesmo configurar índices prováveis de tendências, mas que não necessariamente têm de suceder no tempo de algum modo ou padrão recorrente ou previsível. Ou seja: ao contrário do que sucede com a estabilidade política, aqui os fatores tempo e reiteração não têm, por si sós, o mesmo peso relativo e comparativamente uniformizante ${ }^{25}$. Assim, de acordo com essa tipologia, um contexto político particular pode evoluir ou variar desde uma situação de polarização em torno de issues, policies e programas específicos - o que seria o nível mais elevado e corriqueiro de despolarização de qualquer regime político razoavelmente plural e competitivo $(P P=0)-$, passando por uma polarização de caráter mais ideológico: em que os mesmos issues específicos já assumiriam uma feição e uma vinculação (supostamente) mais consistentes em termos ideológicos, permitindo, inclusive, sua associação com outros temas, de um modo que não ocorreria no nível anterior (nesse caso, PP $=0,25$ ). A partir daí se poderia pensar em contextos em que a polarização (mais ou menos ideologizada) já assumiria um caráter faccioso e concreto mais conspícuo, associando-se a agenda a disputas personalizadas entre líderes, seus séquitos e bases $(P P=0,5)$. Com a elevação da temperatura política, poderíamos pensar agora já num contexto mais radicalizado e até mesmo protoinsurrecional, em que tais grupos, facções ou partidos, concretamente identificados na arena, se polarizam, conspiram e se ameaçam ( $P P=0,75)^{26}$. Finalmente, pode-se chegar às "vias de fato", com a polarização não permitindo mais qualquer posição de neutralidade, com a radicalização explodindo em insurreições e, no limite, em guerra civil (PP = 1).

modo geral, porém, acredito que sem uma mudança do primeiro fator (regras), seria pouco provável a ocorrência significativa do segundo (oferta).

25 Outros fatores - que não explorarei aqui - como a evolução de contextos socioeconômicos ou a ação de lideranças políticas e ideológicas, podem desempenhar papel central (ver, por exemplo, Przeworski, 2006).

${ }^{26} \mathrm{E}$ em que, conforme a teoria poliárquica dahlsiana, os custos de tolerância entre adversários políticos equiparam-se ou mesmo começam a suplantar os custos de supressão (Dahl, 1997). 
Ora, se aplicássemos essas categorias aos seis contextos eleitorais pós-Regime Militar, creio que teríamos os seguintes cenários ${ }^{27}$ :

1) 1989: sendo essa a primeira eleição presidencial em quase 30 anos, não há dúvidas de que a estabilidade política, tal como especificada aqui, seria então a mais baixa possível $(E P=0)$; quanto à polarização política, creio que se pode dizer que assistimos naquele ano a uma disputa eleitoral claramente ideologizada (PP = $0,25)$. Dado o contexto de grave crise econômica por que passava o país, as eleições se decidiram no segundo turno, entre candidatos que, mais do que se contrapor em termos de propostas muito concretas - e também em termos de séquitos personalizados consistentemente -, representavam, não obstante, duas grandes alternativas de enfrentamento da crise: de um lado, digamos, certo neoliberalismo de ocasião, de outro, um estatismo mais voluntarista do que propriamente consequente ${ }^{28}$;

2) 1994: embora aqui estivéssemos diante de uma eleição geral - e não solteira, como em 1989 -, a inexistência de grandes alterações nas regras da disputa presidencial e a presença basicamente das mesmas agremiações partidárias, em todo o espectro ideológico tradicional, caracterizaram uma importante continuidade institucional ( $E P=0,25)$; já no que diz respeito ao índice de $\mathrm{PP}$, creio que dessa vez a eleição perdeu muito de seu caráter ideologizado em função da predominância na agenda de um único tema ou divisor de águas mais concreto e específico: a favor ou contra o Plano Real (logo, PP =0);

3) 1998: nessa eleição estivemos novamente diante de uma inovação institucional significativa, no caso, a possibilidade de reeleição do chefe do Poder Executivo (pela primeira vez, na República); mas creio que essa importante mudança não se refletiu em grandes alterações de caráter estratégico para o eleitor (dada a continuidade dos fatores principais já mencionados); por isso, creio que a estabilidade política avançou, tal como a caracterizo aqui ( $E P=0,5)$; de modo similar ao último pleito, creio que a polarização política se manteve nos mesmos quadros da eleição anterior, em torno da manutenção do Plano Real ( $P P=0)$;

\footnotetext{
27 Como poderá ser observado, minha síntese das conjunturas eleitorais do pós-1988 se estrutura única e exclusivamente com o intuito reducionista de responder ao desempenho de cada uma das variáveis independentes do modelo. Ou seja: particularmente os índices de polarização política (PP) atribuídos podem variar enormemente em seus conteúdos empíricos concretos - tendo por razões principais fatores conjunturais de ordem técnica, ideológica, moral (corrupção, escândalos etc.), graus de incerteza competitiva, estratégias de campanha mais ou menos agressivas etc. -, que, por si sós, pouco importam para o experimento. O que se procura "mensurar" com a formalização tipológica é como essa variável se apresenta numa escala ideal de intensidade de confrontação política (partidária), independentemente das razões empíricas específicas que a motivam.

${ }^{28} \mathrm{E}$ ambos unificados numa rejeição moralista aos partidos mais tradicionais da chamada Transição Democrática (Lattman-Weltman, Ramos e Carneiro, 1994).
} 
4) 2002: mesmo sendo essa a eleição que talvez marque a mais importante alternância regulamentar e pacífica de poder em toda a história republicana brasileira ${ }^{29}$, com a chegada de um grande partido de massas - e de esquerda - ao governo central, a estabilidade política manteve sua tendência crescente inalterada $(E P=0,75)$; e, talvez não por acaso, também a polarização política manteve seu estilo moderado, tal como desde 1994: em torno de issues e programas, e não em torno de ideologias ou (ainda) séquitos $(P P=0)^{30}$;

5) 2006: a estabilidade política atingiu aqui seu ponto mais alto, nos limites do modelo, dada a manutenção das coordenadas eleitorais principais (e, portanto, a $\mathrm{EP}=1,0)$; mas a polarização modificou-se substancialmente: com a crise do Mensalão, no ano anterior, o contexto assumiu - e pela primeira vez, desde a democratização ${ }^{31}$ - uma feição clara de polarização personalizada, em torno e em oposição a Lula e a seu partido (logo, PP =0,5);

6) 2010: aqui houve nova vitória do PT, agora com Dilma Rousseff, e com os mesmos indicadores do pleito anterior: $E P=1$ e $P P=0,5$; já que, além de ser mais uma eleição dentro dos mesmos parâmetros anteriores, manteve-se também a mesma polarização de cunho personalista.

7) 2014: mantida a continuidade no que diz respeito à estabilidade ( $E P=1)$, essa, sem dúvida, foi a mais polarizada, radical e agressiva (e eleitoralmente acirrada) de todas as eleições disputadas sob o marco da Constituição de 1988. E creio não ser exagero qualificar tal cenário de polarização como sendo do tipo protoinsurrecional $(P P=0,75)^{32}$.

De posse desses indicadores, podemos então "deduzir", conforme o modelo, os efeitos de EP e PP sobre o que seriam índices de preferências, de margens de risco, de utilidades atribuídas à informação e, consequentemente, de influências midiáticas típicas para cidadãos comuns e militantes no período, conforme a Tabela $1^{33}$ :

\footnotetext{
29 Se não, simplesmente, em toda a nossa história.

30 Dessa vez, porém, não mais o Plano Real - já devidamente incorporado por todos os principais partidos mas sim a retomada do crescimento econômico e o combate ao desemprego. E de um modo ainda mais vago e impreciso, ou tão vago e impreciso, quanto o dos receituários de saída da crise em 1989. A rigor, creio que se pode dizer que 2002 se desenrolou essencialmente em torno de apostas sobre quem teria melhores chances de aprimorar a economia e fazer a estabilidade do Real alavancar também o crescimento. Como se dizia na época, sobre quem poderia melhor encarnar as esperanças de melhores dias. Nesse sentido, não creio que tenhamos visto desde a redemocratização uma eleição presidencial menos polarizada do que essa. ${ }^{31}$ A rigor, desde o período anterior ao golpe de 1964, na chamada Democracia de 1946.

32 Basta lembrar o contexto imediatamente pós-eleitoral, ainda em 2014, assim como o do segundo mandato de Dilma, para confirmar a especificidade histórica desse momento, o qual, mais do que qualquer outro, mereceria a popular alcunha de "terceiro turno" (um longo "terceiro turno").

33 Para melhor visualização do potencial do modelo, acrescentei à tabela-base (Tabela 1) o ano de 2016, em que não foram realizadas eleições presidenciais - e sim municipais - mas já nos encontrávamos sob as novas condições políticas e institucionais ocasionadas não somente pelo impeachment de Dilma, nesse mesmo ano, mas também pelo novo status quo que a ele se seguiu (ou seja, o governo Temer e sua agenda de reformas). No sentido de que ambos os eventos configuram sérios abalos, se não mesmo rupturas, na trajetória de estabilização política do país. Quer dizer: mesmo que não voltemos exatamente à estaca zero $(E P=0,0)$, a redução comparativa dessa variável fundamental não deixaria de ser significativa.
} 
Tabela 1

Aplicação do modelo a cidadãos comuns (AVGs) e a militantes (MILs) nas eleições presidenciais de 1989 a $2014(2016)^{34}$

\begin{tabular}{|l|c|c|c|c|c|c|c|c|c|c|}
\cline { 3 - 12 } \multicolumn{1}{c|}{} & \multicolumn{1}{c|}{ AVGs } & MILs \\
\hline Eleições & EP & PP & Pra & MRa $_{\mathbf{a}}$ & $\mathbf{U I}_{\mathbf{a}}$ & $\mathbf{I M}_{\mathbf{a}}$ & $\mathbf{P r}_{\mathbf{m}}$ & $\mathbf{M R}_{\mathbf{m}}$ & $\mathbf{U I}_{\mathbf{m}}$ & $\mathbf{I M m}_{\mathbf{m}}$ \\
\hline 1989 & 0,00 & 0,25 & 0,25 & 0,25 & 0,00 & 2,00 & 0,50 & 0,50 & 0,50 & 2,25 \\
\hline 1994 & 0,25 & 0,00 & 0,50 & $-0,25$ & $-0,75$ & 1,63 & 0,25 & 0,00 & $-0,25$ & 1,88 \\
\hline 1998 & 0,50 & 0,00 & 1,00 & $-0,50$ & $-1,50$ & 1,25 & 0,50 & 0,00 & $-0,50$ & 1,75 \\
\hline 2002 & 0,75 & 0,00 & 1,50 & $-0,75$ & $-2,25$ & 0,88 & 0,75 & 0,00 & $-0,75$ & 1,63 \\
\hline 2006 & 1,00 & 0,50 & 2,50 & $-0,50$ & $-3,00$ & 0,50 & 2,00 & 1,00 & 0,00 & 2,00 \\
\hline 2010 & 1,00 & 0,50 & 2,50 & $-0,50$ & $-3,00$ & 0,50 & 2,00 & 1,00 & 0,00 & 2,00 \\
\hline 2014 & 1,00 & 0,75 & 2,75 & $-0,25$ & $-3,00$ & 0,50 & 2,50 & 1,50 & 0,50 & 2,25 \\
\hline 2016 & 0,00 & 0,75 & 0,75 & 0,75 & 0,00 & 2,00 & 1,50 & 1,50 & 1,50 & 2,75 \\
\hline
\end{tabular}

Fonte: Elaboração própria utilizando as fórmulas apresentadas no Anexo.

Como podemos observar, a primeira evolução digna de nota é a quase inversão que teria se dado entre nossas variáveis independentes ao longo do período: enquanto a estabilidade política (EP) teria avançado sempre linearmente (até o ápice em 2006, e mantendo-se aí até 2016) - bastando, para isso, inicialmente, a manutenção dos parâmetros básicos do jogo eleitoral no sistema partidário brasileiro -, a polarização política (PP) apresentaria comportamento muito diverso e, em certa medida, oposto. Como se pode visualizar melhor no Gráfico 1, a polarização relativamente ideologizada da primeira eleição presidencial pós-Ditadura teria sido em seguida superada por um enfrentamento mais especificado em torno do Plano Real, que se manteria por mais de uma década, até que a polarização política nacional assumisse novos contornos nas três últimas disputas. Se em 2006 e 2010 a nova radicalização política não parece afetar o desempenho da estabilidade geral do sistema, a partir de 2014, inclusive, a pressão dessa radicalização se faria sentir de modo mais dramático e o resultado se refletiria, afinal, na queda abrupta de EP, consumada em 2016.

Como isso teria se refletido na fixação e na intensidade das preferências, e nas margens de risco dos cidadãos comuns e dos militantes, tal como propõe o modelo?

\footnotetext{
34 Observe-se apenas que, para efeitos de ilustração, os "índices" finais de IM, que poderiam apresentar notação negativa, foram todos normalizados (sobre as fórmulas utilizadas para a confecção da Tabela 1, ver o Anexo).
} 


\section{Gráfico 1 \\ Evolução da estabilidade política (EP) e da polarização política (PP) de 1989 a 2016}

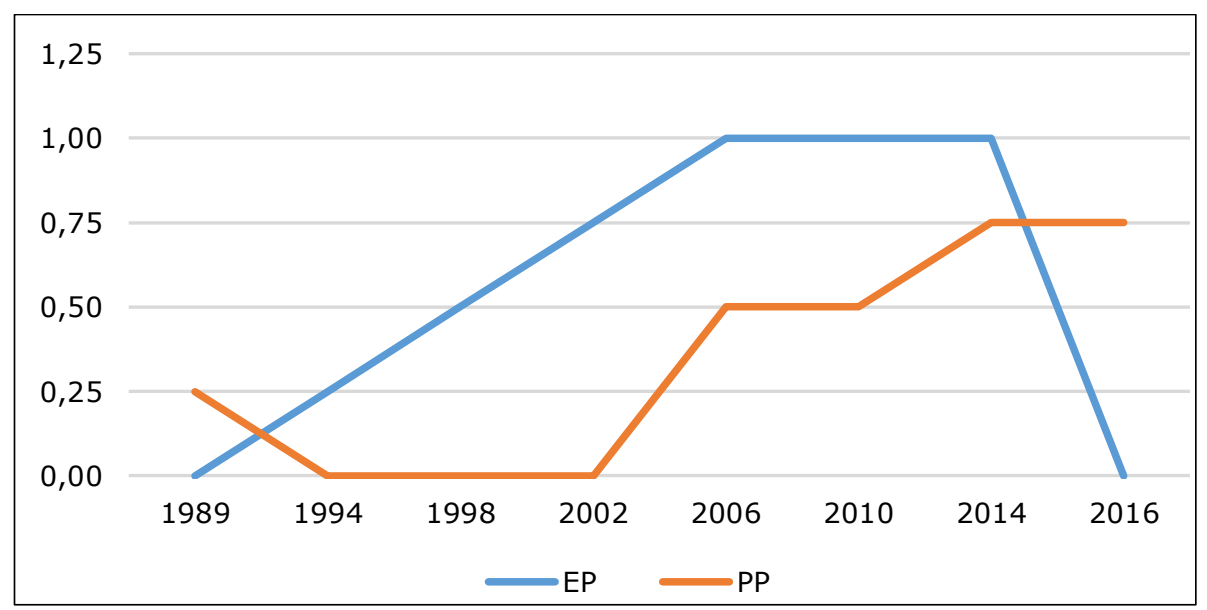

Fonte: Elaboração própria utilizando as fórmulas apresentadas no Anexo.

Como sugeri acima, a estabilidade política e os níveis de polarização política interferem diferentemente sobre esse segundo grupo de variáveis dependentes, mas também intervenientes. Para os chamados cidadãos comuns, o modelo prevê que a EP exercerá uma grande influência direta sobre a fixação das preferências, assim como a polarização política também atuará sobre a intensidade dessas mesmas preferências. Ou seja: pressuponho que, à medida que as regras políticas são reiteradas e praticadas, o cidadão comum tenderia a consolidar as suas preferências políticas (seja em termos de policies, seja em termos de lideranças e/ou siglas partidárias etc. $)^{35}$. De modo similar, quanto mais intensa a polarização política, mais intensificadas tenderiam a ser também as preferências adquiridas por esse mesmo cidadão. Dado que o cidadão comum, por definição, tende a envolver-se de modo menos frequente e intenso na vida política fazendo-o típica e idealmente somente nas eleições periódicas e nas consultas populares formais eventuais -, EP exerceria sobre suas preferências um peso ponderadamente mais decisivo do que PP. Conforme se pode observar na Tabela 1, ao longo do período em questão, a fixação das preferências desse cidadão comum hipotético teria evoluído

\footnotetext{
35 Mais uma vez, é preciso deixar claro que, quando falo em fixação e intensidade de preferências, não pretendo com isso fazer referência a atitudes e posições políticas mais ou menos claras e autodescritivas tais como aquelas que tipicamente se procura identificar em muitos surveys e enquetes. Concordo com toda uma linha de investigação sobre opinião pública e pesquisas de opinião que enfatizam a efetiva pequena consistência formal de tais posições independentemente das pesquisas que as formulam (Zaller, 1993; Stimson, 2004). Por outro lado, também não desprezo o quantum de racionalidade circunscrita que qualquer eleitor comum típico é capaz de mobilizar a partir de relativamente escassos insumos informacionais. Ou seja: mesmo que tenha dificuldade em articular suas razões, quando interpelado, acredito que esse eleitor (em suma: qualquer eleitor) pode ser perfeitamente racional em suas escolhas eleitorais, sejam quais forem suas preferências e motivos (Popkin, 1994; Delli Carpini e Keeter, 1989). E ainda mais racionais coletivamente (ou seja: em agregação). Ver Page e Shapiro (1992).
} 
positivamente: de 0,25 em 1989 para 2,75 na última eleição presidencial (tendendo a sofrer abalos em 2016). Essa tendência por longo tempo crescente seria função, portanto, de EP (que também evolui no mesmo sentido). Mas sua aceleração relativa entre 2002 e 2006, se daria justamente por conta do impacto de uma PP crescente sobre as intensidades das suas preferências adquiridas e fixadas (por EP, em especial), conforme se pode observar no Gráfico 2. Como propus acima, essa polarização relativa se teria dado, no período em questão, por força da crise do Mensalão (2005):

Gráfico 2

Evolução de Pr nas eleições presidenciais de 1989 a 2014 (2016), para cidadãos comuns (AVGs) e militantes (MILs)

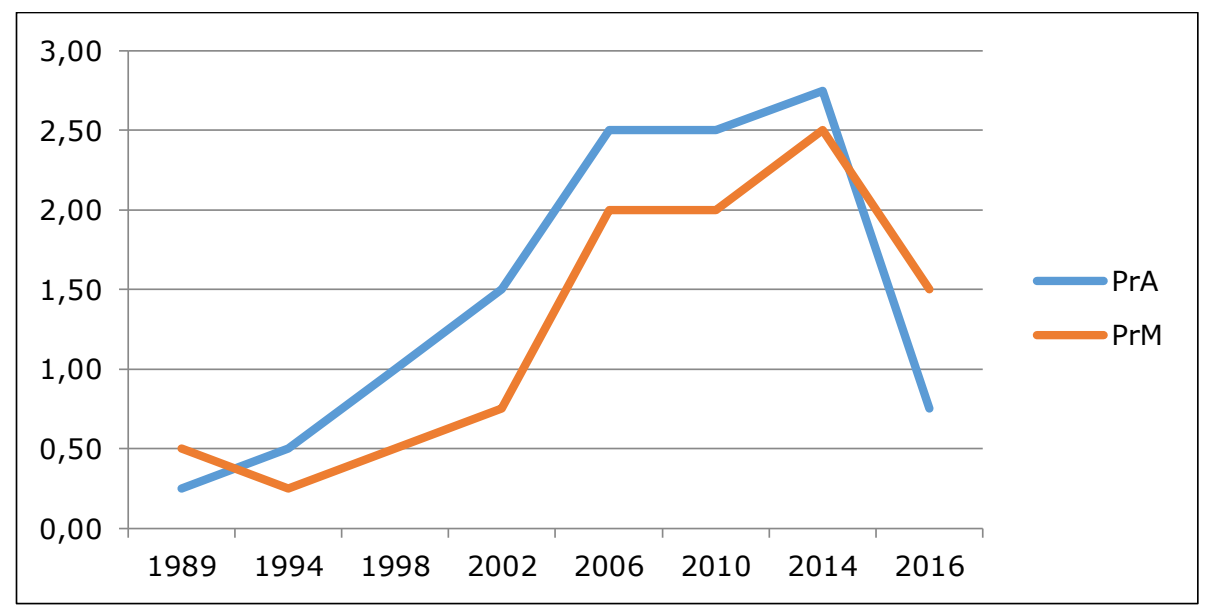

Fonte: Elaboração própria utilizando as fórmulas apresentadas no Anexo.

De acordo com as mesmas variáveis, porém, as preferências do militante típico teriam evoluído praticamente no mesmo sentido, só que, a partir do mesmo evento, em patamares variáveis de fixação e intensidade quando comparadas às dos cidadãos comuns típicos. Isso se daria porque, obviamente, as preferências do militante seriam comparativamente mais sensíveis a alterações da polarização e em função de muitas outras variáveis específicas ao seu contexto de engajamento particular. O peso das variáveis independentes aqui, portanto, é diverso, pois para o militante a EP é sempre mediada por seu campo de engajamento mais específico - não tendo, pois, o mesmo peso independente que possuiria no caso da $\operatorname{Pr}$ do cidadão comum -, ao passo que PP, inversamente, seria muito mais impactante. A rigor, para um autêntico militante, não existe situação propriamente despolarizada. Seja qual for a razão da polarização, esta seria vivenciada sempre de modo muito mais intenso. Desse modo, para este (e ao contrário do 
que sucede com AVGs): $\operatorname{Pr}=P P^{*} 2^{36}$. E por isso também as sutis diferenças e até inversões entre os índices hipotéticos de fixação e intensidade de preferências entre AVGs e MILs, conforme as variações conjunturais de EP e de PP (Gráfico 2).

A outra variável dependente, porém interveniente, do modelo é a margem de risco associada a escolhas do indivíduo, cidadão comum ou militante (MR). Conforme o Gráfico 3, observa-se que, de acordo com o modelo, as MRs de cidadãos comuns e militantes teriam tido evolução simétrica, correspondendo aos segundos, é claro, índices sempre superiores de margens de risco. Em ambos os casos a variável teria apresentado inicialmente uma tendência sempre decrescente, assumindo seu ponto mais baixo em 2002, de onde voltou a apresentar ligeiro crescimento (por conta da conjuntura específica já relatada), e estabilizando-se nesse patamar na última eleição. Isso se dá porque, tanto para um grupo quanto para o outro, MR evolui de modo inversamente proporcional em função de EP e em simetria a PP: quanto maior EP, mais negativa a primeira; ao passo que, à medida que PP cresce, $M R$ a acompanha $(M R=(E P *(-1))+P P)$. Apenas o impacto das variações de PP é sempre mais forte sobre o militante típico; não só porque este tem sempre mais a ganhar ou a perder com as escolhas que faz, mas também porque tende a valorizar o impacto de sua participação política numa proporção muito superior - se não infinitamente superior - ao que ocorreria com o cidadão comum típico.
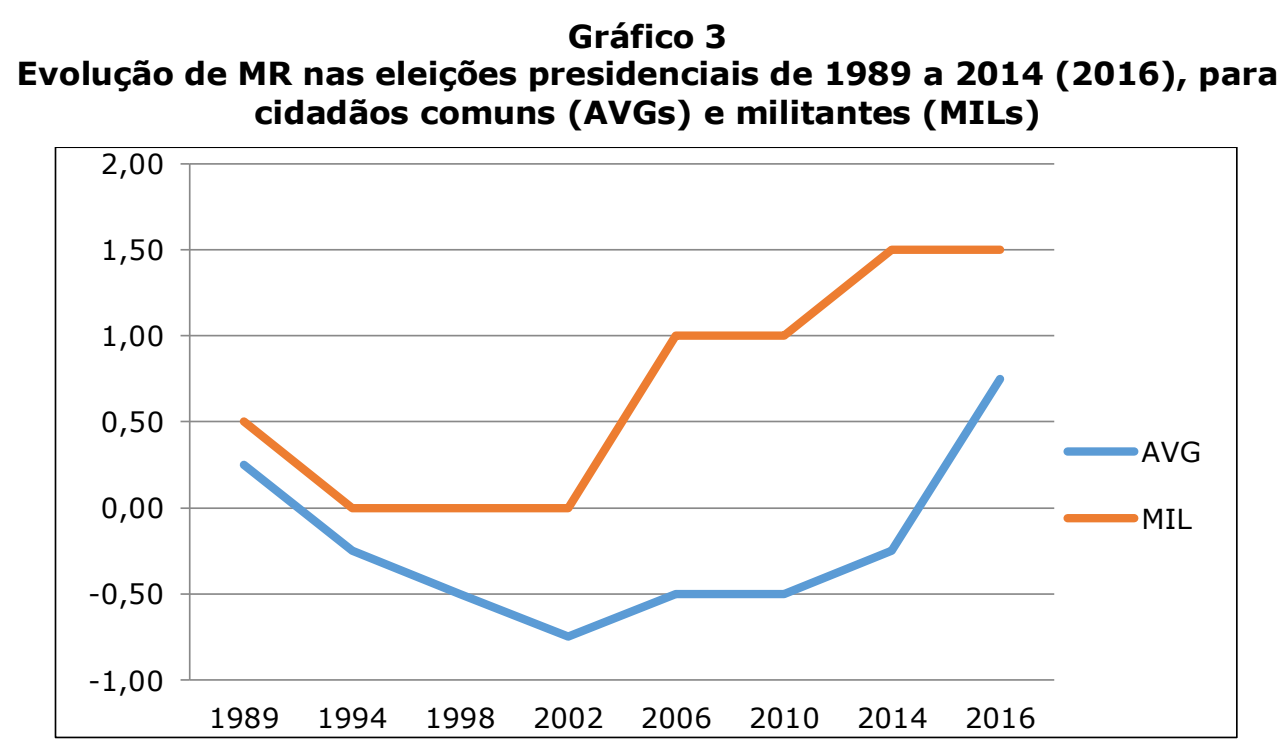

Fonte: Elaboração própria utilizando as fórmulas apresentadas no Anexo.

Observe-se, inclusive, o modo como: 1) MR diminuiria mais fortemente para cidadãos comuns (AVGs) do que para os militantes (MILs) entre 1994 e 1998; 2) elevar-

\footnotetext{
36 Ou seja: em função de variáveis contextuais específicas, a rigor EP pode ser negligenciada aqui em sua interferência direta sobre a fixação e a intensidade das preferências dos militantes típicos.
} 
se-ia mais dramaticamente para os militantes entre 2002 e 2006; 3) assim como aumentaria comparativa e significativamente mais para os primeiros (AVGs) do que para o outro grupo no rumo dos acontecimentos de 2016. Trata-se justamente dos efeitos diferenciados que EP e PP exerceriam sobre cada um dos dois grupos típico-ideais. Já que, enquanto a MR dos militantes reagiria mais rápida e fortemente diante da evolução da polarização - no caso, posta em movimento por uma crise política como a do Mensalão -, e assim a continuidade de tal processo manteria altas as margens de risco, ou as aumentaria para esse grupo, para os cidadãos comuns a insegurança tenderia a aumentar muito mais em função da eventual perda de estabilidade (que, como vimos, se deu ao final do período em questão).

Dadas essas evoluções específicas de cada uma dessas variáveis, a evolução consequente da variável-chave - porém dependente - do modelo confirmaria a hipótese teórico-substantiva: como se pode observar no Gráfico 4 (e de acordo com os dados da Tabela 1), enquanto haveria uma tendência ininterrupta, mas apenas estabilizada, de queda da influência midiática relativa (IM) entre os cidadãos comuns ao longo desse período - invertida dramaticamente, é claro, no período de crise, entre 2014 e 2016 -, no caso dos militantes a tendência inicial de queda - mesmo que em patamares obviamente superiores - se alteraria, contudo, no ponto de inflexão já mencionado, e apresentaria um sentido inverso ao do grupo anterior.

\section{Gráfico 4}

Evolução de IM nas eleições presidenciais de 1989 a 2014 (2016), para cidadãos comuns (AVGs) e militantes (MILs) e diferenças entre os tipos

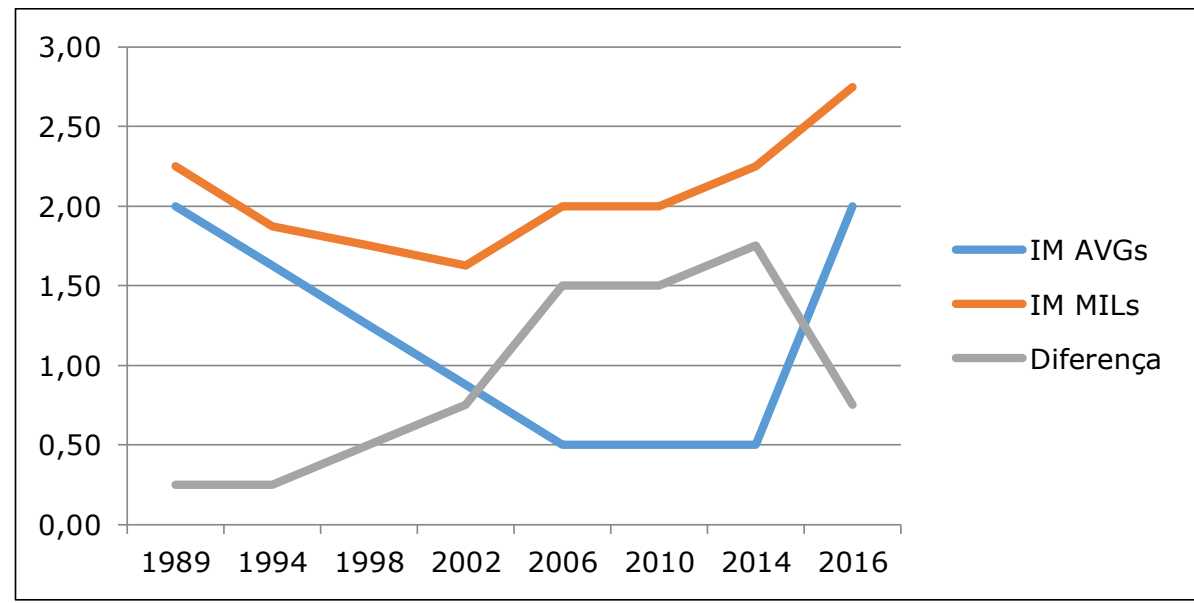

Fonte: Elaboração própria utilizando as fórmulas apresentadas no Anexo.

Ou seja: a partir da crise do Mensalão (2005), o peso da variável-chave (IM) assumiria um sentido significativamente diferente para cidadãos comuns, de um lado, e 
militantes, de outro. Como, na verdade, IM é função da utilidade da informação (UI) ${ }^{37}$, enquanto o primeiro grupo ( $A V G$ ) se veria muito mais fortemente influenciado pela estabilidade política (EP) geral - que, como visto, tem um peso preponderante sobre suas preferências ( $\mathrm{Pr}$ ) e margens de risco (MR) (como pode ser observado no Gráfico 5) - o segundo grupo, dos militantes, teria suas demandas por informação muito mais afetadas por suas preferências, mas ainda mais por suas comparativamente elevadas margens de risco. Que, por sua vez, sofreriam impacto muito mais forte das oscilações em termos de polarização, o que acabaria por tornar esse grupo muito mais influenciável pela mídia do que o outro.

Particularmente interessante é a variação da diferença entre os índices de IM para

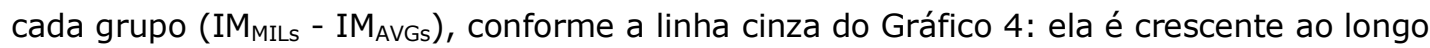
de todo o período, acelerando-se, como esperado, entre 2002 e 2006, mantendo a tendência geral por mais duas eleições, até reduzir-se no contexto da crise dos últimos anos (mas sendo sempre positiva). Ou seja: a influência midiática foi (e, acredito, sempre é) comparativamente maior entre os militantes do que entre os cidadãos comuns. Porque, obviamente, a utilidade da informação é sempre maior para os primeiros. Em contextos de polarização crescente, contudo, essa diferença pode assumir dimensões verdadeiramente dramáticas, levando os dois grupos a também radicalizar as diferenças de perspectivas entre si com relação ao modo de percepção da própria realidade conjuntural política. E, assim, se para uns a crise se instala num determinado momento, e com determinados significados e implicações mais dramáticas ou urgentes, para outros, tudo pode não passar, por algum tempo, de ruído mais ou menos distante, mas certamente muito menos relevante.

Assim, tendo por base a metáfora espacial exposta no Gráfico 5, se poderia dizer que, enquanto as preferências e margens de risco - e consequentemente a utilidade da informação e a proporcional influência midiática - a que tendem a estar sujeitos os cidadãos comuns teriam evoluído no nosso período em torno das tendências e oscilações da estabilidade política e dos graus de polarização política do sistema político mais amplo ${ }^{38}$, as mesmas variáveis apresentariam, no caso dos militantes, uma evolução em patamares bem mais elevados e simétricos, a partir do mesmo contexto geral, como vemos no Gráfico $6^{39}$ :

\footnotetext{
$37 \mathrm{IM}=\mathrm{UI} / 2$

38 Ampliando-se ao longo do período a assimetria entre o processo de formação e intensificação de preferências (Pr) e os índices de utilidade relativa da informação política (UI).

39 Principalmente, como já sugerido, entre 2002 e 2006.
} 


\section{Gráfico 5 \\ Evolução de Pr, MR e UI para cidadãos comuns (AVGs) - 1989-2016}

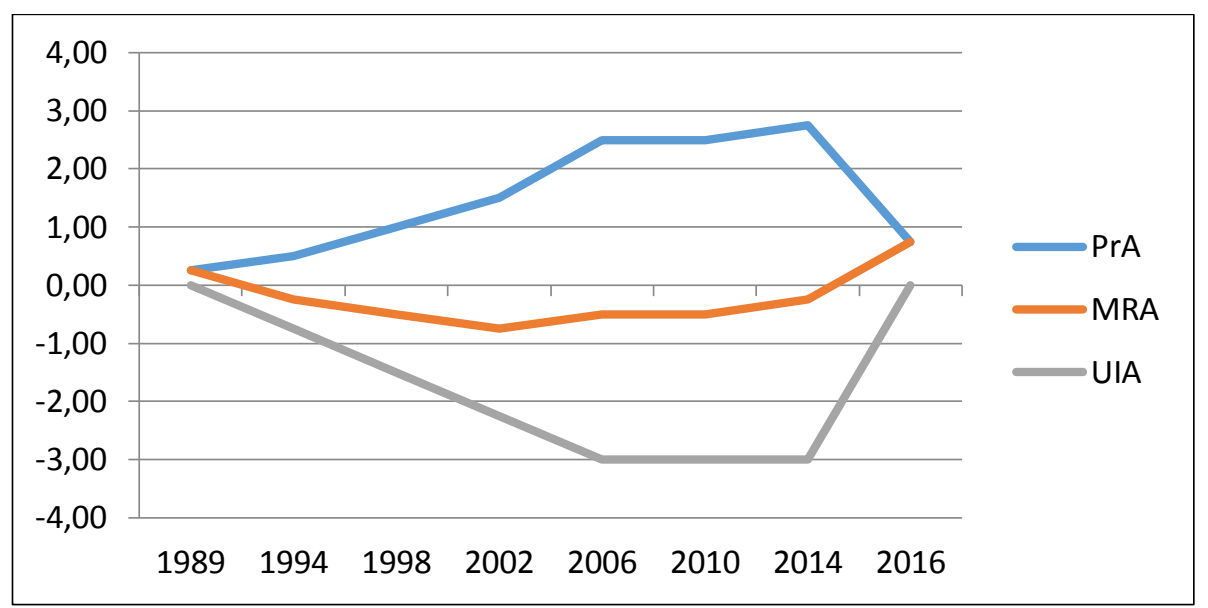

Fonte: Elaboração própria utilizando as fórmulas apresentadas no Anexo.

Nesse sentido, a distância observada entre os índices das variáveis dependentes para cada um dos grupos no período representa graficamente, portanto, em primeiro lugar, o modo como cidadãos comuns e militantes se distinguem em relação a variáveis centrais do jogo político e seus significados. Se para os primeiros a (in)estabilidade política geral se manifesta imediatamente sob a forma essencial da manutenção (ou não) das regras básicas do jogo eleitoral e da oferta, mais ou menos recorrente, de "produtos" e "serviços" políticos - pela ação dos empreendedores, mais ou menos institucionalizados do setor -, para os segundos, a variável "estabilidade" nunca exerce diretamente o mesmo efeito, pois aqui importam muito mais os diferentes resultados contingentes - e frequentemente subsistêmicos - da luta política e ideológica. Lutas cujas eventuais alternância e relativa imprevisibilidade essa mesma estabilidade, a rigor, permite. Assim, no caso dos militantes, se, por um lado, uma instabilidade relativa pode exercer seus efeitos sobre eles de modo comparativamente mais dramático - já que amplia a incerteza e a insegurança -, por outro lado, uma evolução dessa variável no sentido da estabilização - como, acredito, de fato ocorreu ininterruptamente desde 1989 até $2010^{40}$ - não é, necessariamente, sinônimo de redução da incerteza (ou dramaticidade) para os mesmos atores. Na verdade, como aquilo que importa sempre mais para os militantes são os detalhes do jogo cotidiano da luta política - mas em geral vivenciado numa temporalidade bem mais ampla: relativa a conquistas, derrotas, patrimônios e ressentimentos passados, de um lado, e a projetos, expectativas (ou utopias) futuras, de outro -, o mais provável é que, a despeito de uma ou outra evolução geral da variável EP, tais personagens sempre reajam, em termos de

\footnotetext{
40 Para ser mais preciso: provavelmente até 2013.
} 
$\operatorname{Pr}$, MR e, consequentemente, de UI e de IM, de acordo com a evolução específica de PP (e em proporções sempre mais intensas).

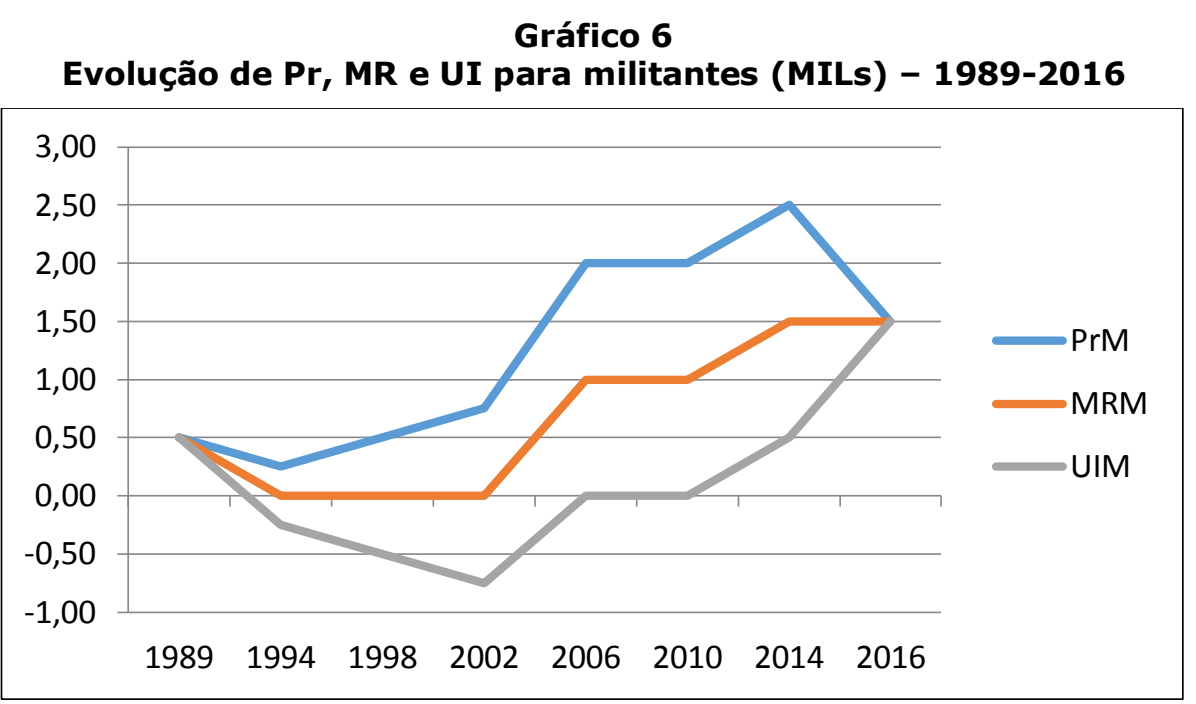

Fonte: Elaboração própria utilizando as fórmulas apresentadas no Anexo.

Assim, de acordo com a mesma lógica, a evolução da polarização política (PP) atuaria também de modo diferenciado para os dois grupos. Para os cidadãos comuns, muitas das formas que a polarização política assume podem ser simplesmente, ou quase, irrelevantes: issues e policies podem não lhes dizer respeito diretamente - ou possuir uma conexão muito tênue ou pouco óbvia com sua realidade imediata -, assim como suas eventuais interações, interdependências e sentidos ideológicos - tão evidentes para os militantes - podem Ihes escapar, ou simplesmente não fazer sentido algum. Polarizações facciosas ou partidárias, que podem ser tão decisivas para a identidade militante, podem não mobilizar o cidadão comum em prol de nenhum dos grupos em disputa. E mesmo num contexto de polarização radical, em que não reste alternativa a esse cidadão comum que não a escolha de um dos lados, esta pode ser para ele uma imposição totalmente externa, involuntária e não definitiva (de pouca duração, inclusive, se o conflito radical não perdurar).

Assim, ao contrário do que pressupõe certa narrativa de "crise da representação", tão recorrente, e que escutamos cada vez mais - tanto na academia quanto principalmente na vulgata que desta se faz -, não seriam os cidadãos comuns, os simples eleitores, os que talvez estivessem mais distantes ou alienados de seus representantes institucionais, em contextos de contínua estabilização política. Mas sim, ao contrário, os chamados militantes. Pois que, em função de seus fortes engajamentos ideológicos, sectários, profissionais e/ou corporativos específicos, estes tenderiam a desenvolver suas próprias pautas, agendas e rationales, suas próprias prioridades, metas e objetivos, de curto, médio 
ou longo prazos, nem sempre congruentes com os de suas possíveis lideranças partidárias efetivas. Principalmente porque, embora tais militantes (ou simpatizantes) sejam estrategicamente muito importantes em muitas circunstâncias da vida partidária democrática contemporânea, não são eles a fonte do principal recurso a que se dirigem os esforços dos empreendedores políticos mais competitivos: o voto. É justamente a maioria esmagadora dos cidadãos comuns que a possui em grande escala, e não as minorias militantes.

E sendo assim, se, por força da complexidade da competição política na democracia de massas contemporânea, os grandes empreendedores políticos se veem forçados a jogar contraditórios jogos simultâneos, e mais ou menos ocultos, uns dos outros ${ }^{41}$, o que os leva a incorrer fatalmente em contradições, não são os cidadãos comuns os que se veriam mais tendencialmente frustrados com as eventuais incongruências de discurso, ou entre o discurso e a prática dos primeiros. Inclusive porque, como já expus acima, especialmente em contextos de relativa estabilidade - e ainda mais se a despolarização for efetiva -, tais cidadãos teriam pouco incentivo para perder tempo e outros recursos com aquisição de novas informações políticas; muito menos em desenvolver grandes expectativas - ou expectativas muito precisas e intensas - com relação aos desempenhos futuros dos candidatos em oferta, uma vez eleitos. Basta para tais cidadãos se valerem das informações - ou atalhos cognitivos - já disponíveis e previamente adquiridas (nesse e em outros jogos já jogados) para escolher. Já o mesmo não pode ser dito, porém, dos militantes; aqui o engajamento maior - e margens de risco comparativamente elevadas conduz não só a um consumo muito mais ávido e intenso de informação como tende a tornar tenso todo o enfrentamento com as contradições e idiossincrasias mais superficiais do comportamento político das principais lideranças (a despeito, inclusive, dos efetivos graus de estabilidade que eventualmente o sistema como um todo possa apresentar).

Cidadãos comuns tenderiam a ser, portanto, duplamente mais "econômicos" do que militantes típicos: não somente despenderiam menos recursos com informação - e, desse modo, seriam potencialmente menos influenciáveis por ela -, como também frequentemente precisariam de menos insumos informacionais para processar suas escolhas políticas.

A distância das variáveis entre os Gráficos 5 e 6, mas em especial a diferença de IMs (Gráfico 4), ilustraria, pois, a fundamental diferença entre a vivência política de cidadãos comuns e de militantes. Enquanto para os primeiros as grandes narrativas de conjuntura política, como as grandes crises, escândalos e enfrentamentos partidários, podem ser apenas enredos novelescos (ou anedóticos) passageiros - e que podem até mesmo alterar ou reforçar (mais ou menos superficialmente) certas predisposições de preferência política, mas poucas vezes o bastante para provocar grandes mudanças de hábitos de consumo informacional e de atenção à vida política -, para os segundos, tais

\footnotetext{
41 Como propõe Tsebelis (1998).
} 
efemérides tendem a se tornar matéria de interesse vital: estratégica para a ação (profissional ou não), quando não puramente essencial para os seus (des)equilíbrios identitários, individuais e coletivos. Matéria, portanto, de insuperável relevância histórica.

Conquanto tais diferenças não sejam mais do que óbvias para qualquer observador da vida política, algumas das suas consequências teóricas não parecem assim tão evidentes ou facilmente aceitas pelo mesmo senso comum.

\section{A título de conclusão: de 1989 a 2014 (e o turning point de 2013)}

De acordo com o modelo e a teoria aqui expostos, portanto, o que em grande parte explicaria a relativa perda de influência político-eleitoral dos principais meios de comunicação brasileiros, especificamente no período 2006-2014 - meios cada vez mais parciais e partidários, e engajados contra as coalizões predominantes e eleitoralmente mais vitoriosas na conjuntura política nacional do período -, teria sido, principalmente, a estabilização do sistema político brasileiro. E apesar de toda a nova e relativa radicalização personalista e facciosa ocorrida no país desde 2005. A aparente contradição entre ambos os processos - e que leva a indagar por que nesse período o engajamento midiático contra a decisão majoritária do eleitorado nos pleitos presidenciais, embora tenha sido causa e consequência da própria radicalização, mostrou-se, contudo, e em grande medida, eleitoralmente inútil - se explica, de acordo com minha teoria, em grande medida, pelas diferenças em matéria de demandas informacionais e consequente exposição à mídia que separam os chamados cidadãos comuns - que constituem majoritariamente o eleitorado nacional (e o de alhures) - e os ditos militantes (incluídos aí os próprios "formadores de opinião").

A partir, possivelmente, de algum ponto em 2013 - provavelmente o fatídico mês de junho -, porém, tal radicalização teria atingido novo patamar, ou significado, e com os desdobramentos específicos daquela conjuntura, à qual se seguiu a duríssima campanha eleitoral de 2014 e seu interminável "terceiro turno", chegaríamos afinal à peculiar, porém autêntica, ruptura da estabilidade institucional em 2016. Estabilidade que vinha sendo mantida por cerca de três décadas da mais inclusiva e "poliárquica" democracia da história nacional.

Ao longo de quase todo o período democrático pós-Constituição de 1988, pois, tanto a variável EP quanto a PP se apresentaram muitas vezes com feições e consequências muito distintas para, de um lado, a grande maioria dos cidadãos brasileiros, e, de outro, a importante e significativa minoria dos setores mais engajados na vida política nacional. A começar, é claro, pelos próprios profissionais da notícia; mas também pelo seu público consumidor mais ávido e exigente: os diversos grupos de militantes - partidários, ideológicos, profissionais etc. - e analistas da mesma realidade. Os quadros do que poderíamos chamar, portanto, da grande e diversa intelligentsia política brasileira contemporânea. 
Para dar conta, pois, desse estado aparentemente paradoxal de coisas, é preciso aceitar, por um lado, o fato de que, se o poder de influência da mídia é real - e, de modo geral, continuamos acreditando nisso -, por outro lado há que se tentar dar conta com mais cuidado e precisão das variáveis que podem circunscrever esse impacto não somente a setores e a públicos consumidores específicos, mas também - e isso pode ser ainda mais decisivo - a contextos políticos e institucionais específicos e independentes. Foi o que, acredito, observamos, grosso modo, de 1989 até a última eleição presidencial $(2014)^{42}$.

Seja como for, uma das grandes vantagens da adoção, como aqui proposto, de um foco sobre a demanda e não sobre a oferta de informações - como foi minha opção metodológica original no passado (e segue sendo a tendência predominante dos estudos da área) - parece se localizar no sentido da superação dos principais vícios e aporias da rica tradição de estudos de influência política midiática. Em especial no que diz respeito às suas armadilhas excessivamente normativas usuais. Ou seja: em vez de criticarmos a oferta efetiva de conteúdo informativo - mesmo o mais evidentemente parcial e desdenhoso dos cânones da deontologia jornalística prevalecente, e seu compromisso com a objetividade - com base em padrões normativos ideais de difícil operacionalização, passamos a nos ater "somente" às condições gerais que interferem sobre a demanda. $\mathrm{E}$ dando conta, desse modo, das ampliações ou reduções conjunturais do poder de influência consequente da mídia na política, a despeito e - o que ainda é metodologicamente mais interessante - independentemente de seus inúmeros e diversos conteúdos concretos.

Certamente que não pretendo negar o valor e a importância dos estudos tradicionais de análise de conteúdo, ou de discursos, enquadramentos etc., nem muito menos retirar importância de debates como os relativos à economia política da comunicação e à chamada democratização das mídias. Mas sim, acredito, abrir uma nova perspectiva teórica e metodológica no enfrentamento de questões que, claramente, a tradição de estudos sobre a oferta de informação não consegue responder. Em especial, aquelas que se referem às variações conjunturais de poder efetivo da mídia enquanto ator político, institucional e/ou (proto)partidário. Para além, é claro, de outras perspectivas de investigação, teórica e empírica, sobre as implicações da teoria aqui explicitada ${ }^{43}$.

\footnotetext{
42 Desde 2013, parece claro que ingressamos em nova conformação sociopolítica, que se deve, em grande parte, a alterações do ambiente informacional global, com impactos massivos sobre o militantismo e a experiência política do chamado cidadão comum. É claro que aqui faço referência à atual revolução comunicacional trazida pelas novas redes midiáticas. Mas isso é assunto para outra ocasião (ver, por exemplo, Martuccelli, 2015).

43 Entre elas, por exemplo, a do próprio interesse, mais ou menos conjunturalmente contraditório, da própria mídia, enquanto ator político e econômico, em subverter a estabilidade institucional democrática, na medida em que quanto maior a instabilidade e a incerteza, maior também a utilidade da informação (UI) e, consequentemente, a influência midiática (IM) (caberia então investigar até que ponto o conjunto das principais mídias no Brasil teria agido justamente nesse sentido, exatamente após a perda conjuntural e relativa de seu poder de influência eleitoral ao longo da era PT (2003-2016)). Mais assunto para outros trabalhos.
} 


\section{Referências bibliográficas}

Abramowitz, A. I. "An improved model for predicting election outcomes". Political Science, Fall, 1988.

Abramowitz, A. I.; SAUnders, K. L. "Is polarization a myth?". The Journal of Politics, vol. 70, n², 2008.

ALDÉ, A. A construção da política. Rio de Janeiro: Editora FGV, 2005.

AldÉ, A.; Mendes, G.; Figueiredo, M. "Tomando partido: imprensa e eleições presidenciais em 2006". Política \& Sociedade, vol. 6, $\mathrm{n}^{\circ}$ 10, 2007.

AzEVEDo, F. A. Mídia e democracia no Brasil: um balanço dos anos recentes. In: GoulART, J. (ed.). Mídia e democracia. São Paulo: Annablume, p. 23-46, 2006.

A grande imprensa e o PT. São Carlos: EdUFScar, 2017.

CoImBra, M. A mídia teve algum papel durante o processo eleitoral de 2006?. In: LimA, V. (org.). A mídia nas eleições de 2006. São Paulo: Perseu Abramo, p. 187-210, 2007.

Colling, L. "Os estudos sobre mídia e eleições presidenciais no Brasil pós-ditadura". Salvador, $432 f$. Tese de Doutorado em Comunicação e Cultura Contemporâneas. Universidade Federal da Bahia, Salvador, 2006.

DAHL, R. A. Poliarquia: participação e oposição. São Paulo: Edusp, 1997.

Delli CARPini, M.; KeETeR, S. What Americans know about politics and why it matters. New Haven/London: Yale University Press, 1989.

Downs, A. An economic theory of democracy. New York: HarperCollins, 1957.

FIORINA, M. P.; ABRAMS, S. J.; POPE, J. C. Culture war? The myth of a polarized America. New York: Longman, 2011.

Grofman, B. (ed.). Information, participation and choice. Ann Arbor: University of Michigan Press, 1993.

Guazina, L. S.; Prior, H.; Araújo, B. "Enquadramentos de uma crise: o impeachment de Dilma Rousseff em editoriais nacionais e internacionais". In: 70 Congresso da Associação Brasileira de Pesquisadores de Comunicação e Política, Porto Alegre, 2017.

LATTMAN-WeLtMAN, F. "Mídia e democracia: indeterminação e representatividade da representação". Compolítica, vol. 4, n² 2014.

. "Fidelidade ou credibilidade? Desafios políticos ao jornalismo brasileiro contemporâneo". In: $10^{\circ}$ Congresso da Associação Brasileira de Ciência Política - ABCP, Belo Horizonte, 2016.

LATTMAN-WeltMAN, F.; CHAGAS, V. "Insegurança (re)partidarização e 'fogo amigo': a economia política da mídia na Era Lula". Revista Eptic, vol. 19, n², 2017.

LatTman-Weltman, F.; Ramos, P. A.; CARneiro, J. A. A imprensa faz e desfaz um presidente. Rio de Janeiro: Nova Fronteira, 1994.

LAZARSFELD, P.; KATZ, E. Personal influence: the part played by people in the flow of mass communications. New Brunswick: Transaction, 2006.

LEWIS-BECK, M.; RICE, T. W. "Forecasting presidential elections: a comparison of naïve models". Political Behaviour, vol. 6, n 1, 1984. 
DESVENTURAS DA INFLUÊNCIA POLÍTICA MIDIÁTICA NO BRASIL PÓS-1988: UMA TEORIA DA DEMANDA POR INFORMAÇÃO POLÍTICA

MARTUCCELli, D. Esfera pública, movimentos sociais e juventude. In: SoRJ, B.; FAusto, S. (orgs.). Internet e mobilizações sociais: transformações do espaço público e da sociedade civil. São Paulo: Edições Plataforma Democrática, 2015.

Mundim, P. S. "Para uma problematização do voto nos estudos sobre mídia e eleições no Brasil: Esboço de um modelo analítico". In: XII Congresso Brasileiro de Ciências da Comunicação da Região Sudeste da Intercom, Juiz de Fora, 2007.

PAGE, B.; ShAPIRO, R. Y. The rational public: fifty years of trends in Americans' policy preferences. Chicago: University of Chicago Press, 1992.

PAGE, S. E. The difference. Princeton: Princeton University Press, 2007.

POPKIN, S. L. The reasoning voter: communication and persuasion in presidential campaigns. Chicago/London: University of Chicago Press, 1994.

Porto, M. "Enquadramentos da mídia e política". In: $26^{\circ}$ Encontro Anual da Associação Nacional de Pós-Graduação e Pesquisa em Ciências Sociais (Anpocs), Caxambu, 2002.

PRZEWORSKI, A. Self-enforcing democracy. In: WiTMAN, D.; WeingAST, B. (eds.). Oxford handbook of political economy. New York: Oxford University Press, 2006.

Schumpeter, J. Capitalismo, socialismo e democracia. Rio de Janeiro: Fundo de Cultura, 1961.

Stimson, J. A. Tides of consent: how public opinion shapes American politics. Cambridge: Cambridge University Press, 2004.

TSEBeLIS, G. Jogos ocultos. São Paulo: Edusp, 1998.

ZALLER, J. R. The nature and origins of mass opinion. New York: Cambridge University Press, 1993.

\section{Anexo}

\section{Abreviaturas}

AVGs = Cidadãos Comuns;

$\mathrm{EP}=$ Estabilidade Política;

PP = Polarização Política;

$\mathrm{Pr}_{\mathrm{a}}=$ Preferências (cidadãos comuns);

$\mathrm{Pr}_{\mathrm{m}}=$ Preferências (militantes);

MILs = Militantes;

$M R_{a}=$ Margem de Risco (cidadãos comuns);

$\mathrm{MR}_{\mathrm{m}}=$ Margem de Risco (militantes);

$\mathrm{UI}_{\mathrm{a}}=$ Utilidade da Informação (cidadãos

comuns);

$\mathrm{UI}_{\mathrm{m}}=$ Utilidade da Informação (militantes);

$\mathrm{IM}_{\mathrm{a}}=$ Influência Midiática (cidadãos comuns);

$\mathrm{IM}_{\mathrm{m}}=$ Influência Midiática (militantes).

\section{Fórmulas utilizadas (Tabela 1)}

- Para AVGs:

$\mathrm{Pr}_{\mathrm{a}}=(\mathrm{EP} * 2)+\mathrm{PP}$

$M R_{a}=(E P *-1)+P P$;

$\mathrm{UI}_{\mathrm{a}}=\left(\mathrm{Pr}^{*}-1\right)+\mathrm{MR}$;

$\mathrm{IM}_{\mathrm{a}}=(\mathrm{UI} / 2)+2$.

- Para MILs:

$\mathrm{Pr}_{\mathrm{m}}=\mathrm{EP}+(\mathrm{PP} * 2) ;$

$M R_{m}=P P * 2 ;$

$\mathrm{UI}_{\mathrm{m}}=(\mathrm{Pr} *-1)+(\mathrm{MR} * 2) ;$

$\mathrm{IM}_{\mathrm{m}}=(\mathrm{UI} / 2)+2$. 


\begin{abstract}
Misadventures of media influence in post-1988 Brazil: a theory of political information demand

The article presents a theory of political information demand, and its model is applied to the analysis of the seven Brazilian presidential elections following the transition to democracy. The initial goal of the theory is to posit the potential of the political and electoral influence of the mass media on the choices not only of so-called ordinary citizens, but also of militants, depending on the political and institutional context. In other words, why does intervention on the part of the mass media in certain circumstances seem to have a decisive influence on the choices of some individuals but not in others? How does one discern such variations without the known limits of political information supply analyses, which either do not account for the reception's polysemy, or, which cannot be generalized when they do, on a smaller scale and with more depth. According to this theory, media influence is a function of the utility attributed to political information, which depends on the stability and intensity of voter preferences and the risk margins with which they make their decisions, which in turn depend on the overall stability and degree of political polarization of the political system. Some of the other potentials of the theory are also briefly indicated.
\end{abstract}

Keywords: political theory; media influence; Brazil; elections; militancy

\title{
Resumen
}

Desventuras de la influencia política mediática en Brasil post-1988: una teoría de la demanda por información política El artículo presenta una teoría de la demanda de información política y el modelo aplicado al análisis de las siete elecciones presidenciales brasileñas tras el régimen militar. El objetivo inicial de la teoría es situar el potencial de influencia política y electoral de los medios de comunicación sobre las decisiones de los llamados ciudadanos comunes y de los militantes, conforme variables del contexto político e institucional. Es decir: ¿por qué en determinadas circunstancias la intervención mediática parece influir decisivamente sobre las opciones de los individuos y en otras no? Cómo es posible discernir tales variaciones sin los límites conocidos de los análisis de la oferta de la información política que, o no dan cuenta de la polisemia de la recepción, o, cuando lo hacen, a una escala más reducida y profunda, no pueden generalizarse. De acuerdo con la teoría, la influencia mediática es función de la utilidad atribuida a la información política, la cual depende de la fijación e intensidad de las preferencias del elector y del margen de riesgo con que toma sus decisiones, las cuales, a su vez, dependen de la estabilidad y el grado de polarización política del sistema.

Palabras claves: teoría política; influencia mediática; Brasil; elecciones; militancia

\section{Résumé}

Les mésaventures de l'influence politique des médias au Brésil après 1988: une théorie de la demande d'information politique

L'article présente une théorie de la demande d'information politique et son modèle est appliqué à l'analyse des sept élections présidentielles brésiliennes après le régime militaire. L'objectif initial de la théorie est d'identifier le potentiel d'influence politique et électorale des médias dans les choix de ceux que l'on appelle les citoyens ordinaires et les militants selon des variables de contexte politique et institutionnel. Autrement dit, pourquoi, dans certaines circonstances, l'intervention médiatique semble-t-elle avoir une influence décisive sur les choix des individus et non dans les autres? Comment discerner ces changements sans les limites connues de l'analyse de l'offre d'information politique, qui soit ne font pas état de la polysémie de réception, soit, quand ils le font, à plus petite échelle et en profondeur, ne peuvent pas être généralisés. Selon la théorie, I'influence des médias dépend de l'utilité attribuée à l'information politique, qui dépend elle-même de la fixation et de l'intensité de la préférence de l'électeur et de la marge de risque avec laquelle il prend des décisions, qui, à leur tour, dépendent de la stabilité générale et le degré de polarisation politique du système. Certains des autres potentiels de la théorie sont aussi brièvement indiqués. Mots-clés: théorie politique; influences des médias; Brésil; élections; militantisme

Artigo submetido à publicação em 20 de março de 2018. Versão final aprovada em 3 de agosto de 2018.

Opinião Pública adota a licença Creative Commons CC-BY. 